\title{
Xibalbanus cozumelensis, a new species of Remipedia (Crustacea) from Cozumel, Mexico, and a molecular phylogeny of Xibalbanus on the Yucatán Peninsula
}

\author{
Jørgen OLESEN ${ }^{1, *}$, Kenneth MELAND ${ }^{2}$, Henrik GLENNER ${ }^{3}$, \\ Peter J. VAN HENGSTUM ${ }^{4} \&$ Thomas M. ILIFFE $^{5}$ \\ ${ }^{1}$ Natural History Museum of Denmark, University of Copenhagen, Denmark. \\ ${ }^{2,3}$ Department of Biology, University of Bergen, Norway. \\ ${ }^{4}$ Department of Marine Sciences, Texas A\&M University at Galveston, USA. \\ ${ }^{5}$ Department of Marine Biology, Texas A\&M University at Galveston, USA. \\ ${ }^{*}$ Corresponding author: jolesen@snm.ku.dk \\ ${ }^{2}$ Email: Kenneth.Meland@uib.no \\ ${ }^{3}$ Email: Henrik.Glenner@uib.no \\ ${ }^{4}$ Email: vanhenp@tamug.edu \\ ${ }^{5}$ Email: $\underline{\text { iliffet@tamug.edu }}$ \\ ${ }^{1}$ urn:Isid:zoobank.org:author:6B569425-6BE7-4A73-B165-87E0C097715A \\ ${ }^{2}$ urn:Isid:zoobank.org:author:F858E23C-6BC0-4E32-8372-CADD34E87D5A \\ ${ }^{3}$ urn:lsid:zoobank.org:author:676BA182-8EE0-418F-B3CF-2F547550CF17 \\ ${ }^{4}$ urn:lsid:zoobank.org:author:01FBBF50-F5F7-485C-85F5-FEB2A0606E53 \\ ${ }^{5}$ urn:lsid:zoobank.org:author:3F52E7D3-C2D4-4C5C-B62A-D28BC524B9B4
}

\begin{abstract}
A new species belonging to the crustacean class Remipedia is described from an anchialine cave system on the island of Cozumel (Mexico), and is illustrated and compared morphologically and molecularly (CO1 and 16S) with closely related taxa. Xibalbanus cozumelensis sp. nov., the first remipede described from Cozumel, is morphologically similar to Xibalbanus tulumensis (Yager, 1987) from the Yucatán Peninsula, but the two species are genetically separate from each other (about $10 \%$ in CO1). A phylogenetic (Bayesian) analysis of Yucatán remipede populations based on CO1 and 16S placed them in a monophyletic Xibalbanus (in Xibalbanidae fam. nov.), with X. cozumelensis as most closely related to $X$. tulumensis. The Yucatán Peninsula and Cozumel have been separate since approx. early Cenozoic ( $\sim 65 \mathrm{Ma})$, which suggests allopatric speciation for $X$. cozumelensis $\mathrm{sp}$. nov. and X. tulumensis. However, the comparatively low genetic divergence between the two species may indicate that there has been gene flow between 'mainland' Yucatán and Cozumel long after the geological separation of the two landmasses, e.g., in cave systems under the sea bed, either continuously or sporadically, for example during the Last Glacial Maximum when the sea level was about $120 \mathrm{~m}$ lower than today.
\end{abstract}

Keywords. CO1, 16S, genetic distance, anchialine cave.

Olesen J., Meland K., Glenner H., Van Hengstum P.J. \& Iliffe T.M. 2017. Xibalbanus cozumelensis, a new species of Remipedia (Crustacea) from Cozumel, Mexico, and a molecular phylogeny of Xibalbanus on the Yucatán Peninsula. European Journal of Taxonomy 316: 1-27. https://doi.org/10.5852/ejt.2017.316 


\section{Introduction}

The crustacean class Remipedia currently encompasses 28 recent species, nearly all of which inhabit anchialine caves in coastal regions (Hoenemann et al. 2013; Yager 2013). The Remipedia was not described until late last century, about 36 years ago (Yager 1981). Recent molecular phylogenetic analyses indicate surprisingly that remipedes and hexapods (insects and allies) are closely related suggesting that Remipedia is critical to understanding the emergence of hexapods (Ertas et al. 2009; Reumont \& Burmester 2010). Based on current observational evidence, the biogeographic distribution of remipedes is disjunct, with the greatest species richness in the Caribbean region, two species on Lanzarote (Canary Islands) and one species in Western Australia (Koenemann et al. 2009; Hoenemann et al. 2013). They are commonly found in the coastal saline groundwater mass on heavily karstified landscapes, except for their presence in saline groundwater flooding a submerged lava tube in the Canary Islands. On coastal carbonate landscapes, the coastal aquifer is typically divided into an upper meteoric lens (fresh to slightly brackish) that is separated from saline groundwater below. These two water masses are often divided by a sharp density interface or halocline further inland, but the boundary between them destratifies towards the coast into a mixing zone of typically brackish water (Smart et al. 2006). There are currently three known exceptions to the occurrence of Remipedia in the saline groundwater mass of anchialine caves on land. The first is Speleonectes epilimnius Yager \& Carpenter, 1999, which was recovered from surface water of an anchialine cave in the Bahamas (salinity 3-5 mg/l, Carpenter 1999). The other two examples are Speleonectes kakuki Daenekas et al., 2009 and Xibalbanus cokei (Yager, 2013) comb. nov., both found in offshore, sub-seafloor marine caves from the Bahamas and Belize, respectively (Yager \& Carpenter 1999; Daenekas et al. 2009; Yager 2013).

With 28 species of remipedes described over a period of 34 years, the discovery of a new species of Remipedia is a relatively rare event (Fig. 1). Since observational evidence depends on logistically complicated cave diving, the true diversity of Remipedia is biased towards an underestimation. After the initial discovery of several species in the 1980s (arrow 'A' in Fig. 1), there was a significant rise in the number of described species following increased collecting efforts in the tropical North Atlantic Ocean (arrow 'B' in Fig. 1). These efforts indicate that the Bahamian Archipelago (the Bahamas, Turks and Caicos) is an apparent center of diversity, with 20 species represented out of the total 28 taxonomically-accepted species. In some cases, multiple species sympatrically inhabit the same cave section (Koenemann et al. 2003).

Molecular systematic approaches have also increased the number of documented species, in some cases discovering significant genetic distances of the cytochrome c oxidase subunit 1 (CO1) and 16S rRNA (16S) between morphologically very similar species (Koenemann et al. 2009; Neiber et al. 2012).

Xibalbanus tulumensis (Yager, 1987) was the first remipede described from the Yucatán Peninsula (Mexico). It was described from Cenote Carwash near Tulum $\left(20.274^{\circ} \mathrm{N}, 87.486^{\circ} \mathrm{W}\right)$, and populations considered conspecific were subsequently collected in a number of cave systems near Tulum and further north in Cenote Crustacea near Puerto Morelos (e.g., Neiber et al. 2012, see also map and legends in Fig. 2). However, the population of Xibalbanus tulumensis from Cenote Crustacea has been repeatedly considered a separate species (e.g., Edgecombe et al. 2003; Koenemann et al. 2006; Neiber et al. 2011), because individuals from this local population are significantly larger than those described from the type locality (i.e., Cenote Carwash). Recently, the genetic distance (CO1) between various remipede populations on the Yucatán Peninsula provided evidence for the con-specificity for both the morphologically larger individuals of Xibalbanus tulumensis from Cenote Crustacea and a number of other populations within the Yucatán Peninsula (Neiber et al. 2012). The second remipede species described from the Yucatán Peninsula was the pseudocryptic Xibalbanus fuchscockburni (Neiber et al. 2012), which is located in conduits connected to Cenote Crustacea that are separate from where the morphologically large X. tulumensis individuals are located. Xibalbanus fuchscockburni is morphologically similar 
OLESEN J. et al., A new species of Remipedia and phylogeny of Xibalbanus from Mexico

Table 1. Data for the three specimens of Xibalbanus cozumelensis sp. nov. from Cueva Quebrada (Cozumel) sequenced in this study.

\begin{tabular}{|c|c|c|c|c|c|c|}
\hline Species & $\begin{array}{c}\text { Collecting } \\
\text { date }\end{array}$ & DNA\# & CO1 & $16 S$ & CytB & Voucher \\
\hline X. cozumelensis sp. nov. & 3 Jul. 2014 & $041114-1$ & KX830885 & KX830886 & KX830882 & $\begin{array}{c}\text { ZMUC- } \\
\text { CRU-4793 }\end{array}$ \\
\hline X. cozumelensis sp. nov. & 3 Jul. 2014 & 190116-1 & KX830884 & - & KX830881 & $\begin{array}{c}\text { ZMUC- } \\
\text { CRU-4794 }\end{array}$ \\
\hline X. cozumelensis sp. nov. & 7 Jul. 2014 & $190116-2$ & KX830883 & - & KX815336 & $\begin{array}{c}\text { ZMUC- } \\
\text { CRU-4792 }\end{array}$ \\
\hline
\end{tabular}

to $X$. tulumensis, but a genetic distance (CO1) between these two disjunct populations at the same level as between many other remipedes species provides evidence that $X$. fuchscockburni is a separate species. Later, a new species of Remipedia, originally described as Speleonectes cokei Yager, 2013, was described from Belize, $275 \mathrm{~km}$ to the south of Tulum, Mexico (Yager 2013). This description appeared simultaneously to a revision of the classification of the Remipedia based on molecular data, which grouped the two Yucatán Remipedia in a new genus, Xibalbanus (Hoenemann et al. 2013). The Belize species was not included in this revision, but based on the genus diagnosis for Xibalbanus provided by Hoenemann et al. (2013), the Belize species can be accommodated in this genus as Xibalbanus cokei (Yager, 2013).

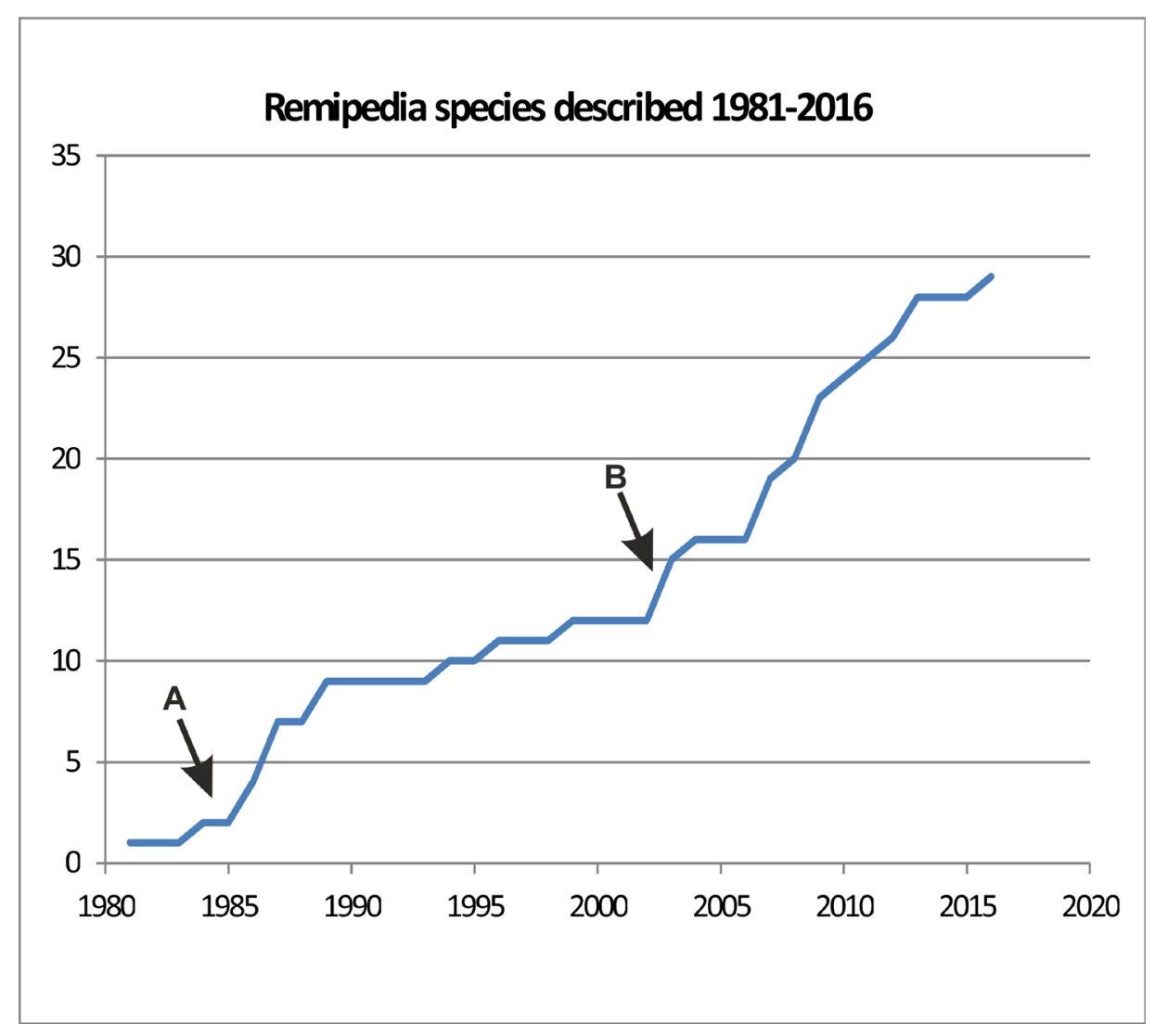

Fig. 1. Described species of Remipedia as accumulated over time (1981 to 2016). A total number of 29 species is known, including Xibalbanus cozumelensis sp. nov. Arrows indicate the onset of significant collecting activities mainly organized by J. Yager in the 1980s (A) and T.M. Iliffe in the 2000s (B). 


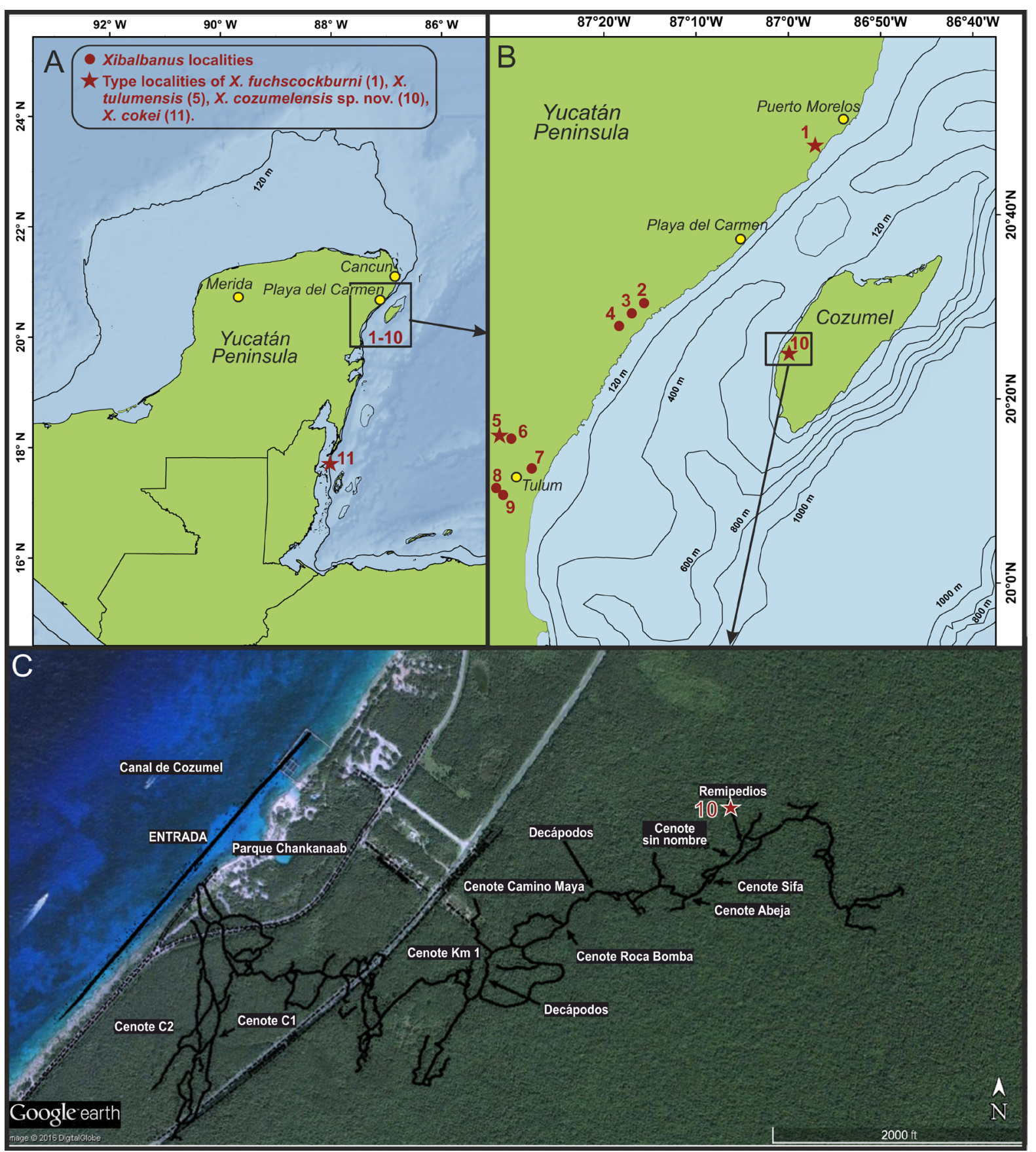

Fig. 2. Maps of the Yucatán Peninsula showing the known distribution of four species of Xibalbanus (Remipedia) and water depths around Cozumel. A. Yucatán Peninsula showing Xibalbanus localities (1-10) in the northeastern region of the Yucatán Peninsula and one locality in Belize further south (11). B. Close-up of the northeastern region of the Yucatán Peninsula with the positions of 10 Xibalbanus localities indicated. C. Close-up of eastern Cozumel with the branches of the anchialine cave "Cueva Quebrada" indicated as an overlay, derived from Yañez-Mendoza et al. (2007). The collecting site of Xibalbanus cozumelensis sp. nov. is indicated as "10". Numbers refer to the following cenotes/caves: 1 = Cenote Crustacea; 2 = Cenote Chac Mool; 3 = Cenote Ponderosa ( $=$ Cenote Jardín del Edén); 4 = Cenote Tajma Ha; 5 = Cenote Carwash (=Cenote Aktun Ha); 6 = Cenote Vaca Ha; 7 = Cenote Temple of Doom (Cenote Calavera, Cenote Esqueleto); 8 = Cenote Naharon (Cenote Cristal); 9 = Cenote Maya Blue (Cenote Escondido); $10=$ Cueva Quebrada; $11=$ Caye Chapel Cave. 1-9 are in the northeastern Yucatán Peninsula, 10 is on the island of Cozumel, 11 is in Belize. 
This paper further explores remipede diversity on the Yucatán Peninsula and describes a new species of Xibalbanus from the island of Cozumel. Cozumel is separated from the north-eastern part of the Yucatán mainland by an approximately $18 \mathrm{~km}$ wide and $400 \mathrm{~m}$ deep channel in the Caribbean Sea (Chávez et al. 2003). The new species is closely related to $X$. tulumensis from the Yucatán Peninsula and its occurrence on Cozumel raises important questions concerning remipede distribution patterns and dispersal.

\section{Material and methods}

\section{Sampling and locality}

Five remipede specimens of Xibalbanus cozumelensis sp. nov. were individually collected in small vials from the anchialine cave, Cueva Quebrada, Cozumel, Quintana Roo, Mexico in July 2014, using advanced technical cave diving procedures. Cueva Quebrada is an $11.5 \mathrm{~km}$-long, flooded cave system in Chankannaab National Park on the west coast of Cozumel. This anchialine cave has 13 cenote entrances and is mostly flooded by the meteoric lens of the local coastal aquifer, which is transporting freshwater from the interior of the island towards the Caribbean Sea. Cueva Quebrada is generally a shallow system with a maximum depth of $9.7 \mathrm{~m}$ below groundwater level containing typically fresh to brackish salinity. In several localities, however, the conduit (cave) geometry is deep enough to transect into the saline groundwater mass near the conduit floor, and this is where the specimens of the new remipede described here were recovered (indicated on Fig. 2). Other previously described stygobiontic species also observed in Cueva Quebrada include the shrimps Procaris mexicana von Sternberg \& Schotte, 2004, Janicea antiguensis (Chace, 1972) and Parhippolyte sterreri (Hart \& Manning, 1981), the amphipods Mayawekelia sp. and Bahadzia sp., and the isopod Metacirolana mayana Bowman, 1987; in addition to the starfish Asterinides pompom (Clark, 1983) (Yañez-Mendoza et al. 2007). Sediment occurring along the cave floor in these localities also included benthic foraminifera Spirophthalmidium emaciatum Haynes, 1973, a foraminifer widely distributed in coastal caves in Bermuda that are also flooded by saline groundwater (Van Hengstum \& Scott 2011). The material of Xibalbanus cozumelensis sp. nov. was deposited at the Natural History Museum of Denmark (ZMUC).

\section{Preservation and preparation of illustrations}

Remipede specimens were preserved in $70 \%$ ethanol and kept at $5{ }^{\circ} \mathrm{C}$ until further analysis. The holotype was examined and illustrated with light microscopy (LM) using an Olympus SZX10 dissection microscope equipped with an Olympus DP73 camera. The habitus (Fig. 3A) was obtained by photographing the holotype specimen at several (about 15) different focus levels thereby obtaining a 'Z-stack', which afterwards was combined in Zerene Stacker (ver. 1.04). Mouth parts and other appendages of the holotype were carefully removed from the body, placed temporarily on a slide under a coverslip (to keep appendage flattened out), and photographed with the same setup as described above (Figs 4, 9). Again, to obtain full depth of focus, a Z-stack was produced and combined in Zerene Stacker. Paratypes were examined in a scanning electron microscope (SEM) (Figs 5-8, 10). The specimens were dehydrated in a graded ethanol series (from 70-100\%), critical point dried, mounted on small metal stubs for SEM, sputter coated with a mixture of palladium and platinum, and observed in an SEM of the type FEI Inspect S.

\section{DNA extraction, amplification, and sequencing}

Extraction of DNA from one trunk segment from each of the three specimens was performed using the 'E.Z.N.A. Insect Kit' (Omega Biotek) following the manufacturer's protocol. Final elution was performed with $100 \mu \mathrm{l}$ Low TE buffer. Extractions are deposited in the Department of Biology, University of Bergen, Norway. Fragments of the mitochondrial CO1 (1251 bp) and cytochrome b (CytB; 430 bp) genes were amplified by polymerase chain reaction (PCR). Two taxon-specific primer pairs where used for CO1 (MH18 + MH19 and MN1 + MN2) (Neiber et al. 2012). Primers 151F (5'-TGTGGRGCNACYGTWATYACTAA-3')and270R(5'-AANAGGAARTAYCAYTCNGGYTG-3') 
(Merritt et al. 1998) were used for CytB. PCR reactions ( $25 \mu \mathrm{l})$ contained $2 \mu \mathrm{l}$ of DNA, $800 \mu \mathrm{M}$ of dNTP (200 $\mu \mathrm{M}$ of each), $2.5 \mu \mathrm{l}$ of x10 Takara Reaction-Buffer (containing $20 \mathrm{mM}$ of $\mathrm{MgCl}_{2}$ ), additional 2 $\mathrm{mM}$ of $\mathrm{MgCl}_{2}$ for $\mathrm{CO} 1$ reactions, $0,4 \mu \mathrm{M}$ of each primer, $0.15 \mu \mathrm{l}(5 \mathrm{U} / \mu \mathrm{l})$ of Takara Ex taq (Takara Bio Inc., Japan) and ddH2O to $25 \mu$ l. PCR reactions were initiated by a denaturation step of 5 min at $94^{\circ} \mathrm{C}$, followed by 5 cycles: denaturation $\left(45 \mathrm{~s}, 94^{\circ} \mathrm{C}\right)$, annealing $\left(30 \mathrm{~s}, 47^{\circ} \mathrm{C}\right)$ and elongation $(1 \mathrm{~min}$, $\left.72^{\circ} \mathrm{C}\right), 30$ cycles: denaturation $\left(45 \mathrm{~s}, 94^{\circ} \mathrm{C}\right)$, annealing $\left(30 \mathrm{sec}, 50^{\circ} \mathrm{C}\right)$ and elongation $\left(1 \mathrm{~min}, 72^{\circ} \mathrm{C}\right)$. Cycling was terminated with a 5 min elongation step at $72^{\circ} \mathrm{C}$. ExoSap purified PCR products were sequenced at the University of Bergen Sequencing Facility. As we were unsuccessful in amplifying a fragment of the mitochondrial large ribosomal subunit (16S) using $16 \mathrm{~S}$ primers, a complete sequence of the mitochondrial large ribosomal subunit (16S) was extracted from the complete mitochondria of one specimen, Xibalbanus cozumelensis (041114-1). A whole genome library was constructed using a 'NEBNext Fast DNA Library Prep Set for Ion Torrent' kit (New England Biolabs). The mitochondria were assembled on gene fragments sequenced on an Ion Torrent PGM, (Contact K. Meland for protocols on library build and PGM sequencing). CO1, CytB, and 16S sequences are deposited in the GenBank ${ }^{\circledR}$ database.

\title{
Distance matrices, alignment, and tree reconstruction
}

CO1 (3 specimens) and 16S (1 specimen) sequences from Xibalbanus cozumelensis $\mathrm{sp}$. nov. from Cozumel (Table 1) were compared with corresponding remipede gene fragments retrieved from GenBank ${ }^{\circledR}$ and combined in a distance matrix (Table 2). CytB ( 3 specimens) was also sequenced but not used further since limited comparative information were available in GenBank $^{\circledR}$. Sequences were aligned using the CLUSTAL W algorithm (Thompson et al. 1994) implemented in Geneious version 8.1.7, and trimmed to equal length. Calculations of uncorrected pairwise genetic distances among sequences (pairwise deletion of gaps) were performed using MEGA 6.05 (Tamura et al. 2013). An independent model of sequence evolution for $\mathrm{CO} 1$ and $16 \mathrm{~S}$ was selected using the Akaike information criterion in MrModeltest 2.3 (Nylander 2004). Model testing suggested a general-time reversible model (Rodríguez et al. 1990) with gamma distributed substitution rates and an estimated proportion of invariable sites $(\mathrm{GTR}+\mathrm{I}+\mathrm{G})$ for both sequences. A Bayesian mixed model phylogeny for CO1 and 16S was constructed using MrBayes 3.1.2 (Ronquist \& Huelsenbeck 2003). Two independent MCMC searches, 4 million generations each, were performed in parallel with three hot and one cold chain. Trees were sampled every 100 generations. The average standard deviation of spilt frequencies (SDSF) after 4 million generations was 0.0054 . Parameter values were evaluated by examining results in Tracer 1.3 (Rambaut et al. 2014). Plots from Tracer were used to determine that the initial 2500 trees from each run ought to be discarded as "burnin". In effect, a total of 75000 trees were used to summarize model parameters and to calculate Bayesian posterior probabilities for nodes of a $50 \%$ majority rule consensus tree (Fig. 11).

\section{Results}

Subphylum Crustacea Brünnich, 1772

Class Remipedia Yager, 1981

Order Nectiopoda Schram, 1986

Family Xibalbanidae fam. nov.

urn:1sid:zoobank.org:act:920F5F9D-BC04-4D64-8EA2-E3495D03C493

\author{
Type genus \\ Xibalbanus Hoenemann, Neiber, Schram \& Koenemann, 2013.
}




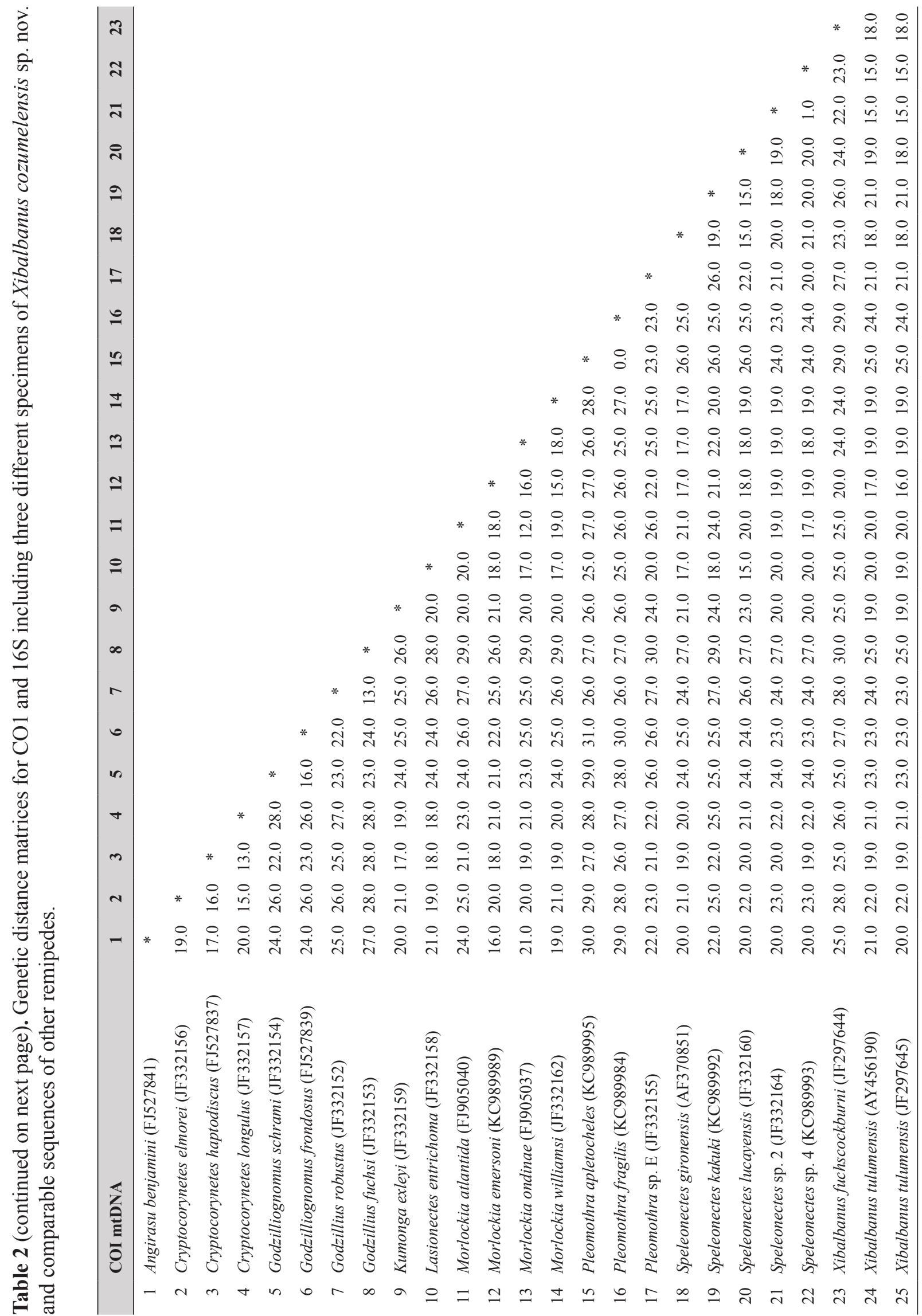




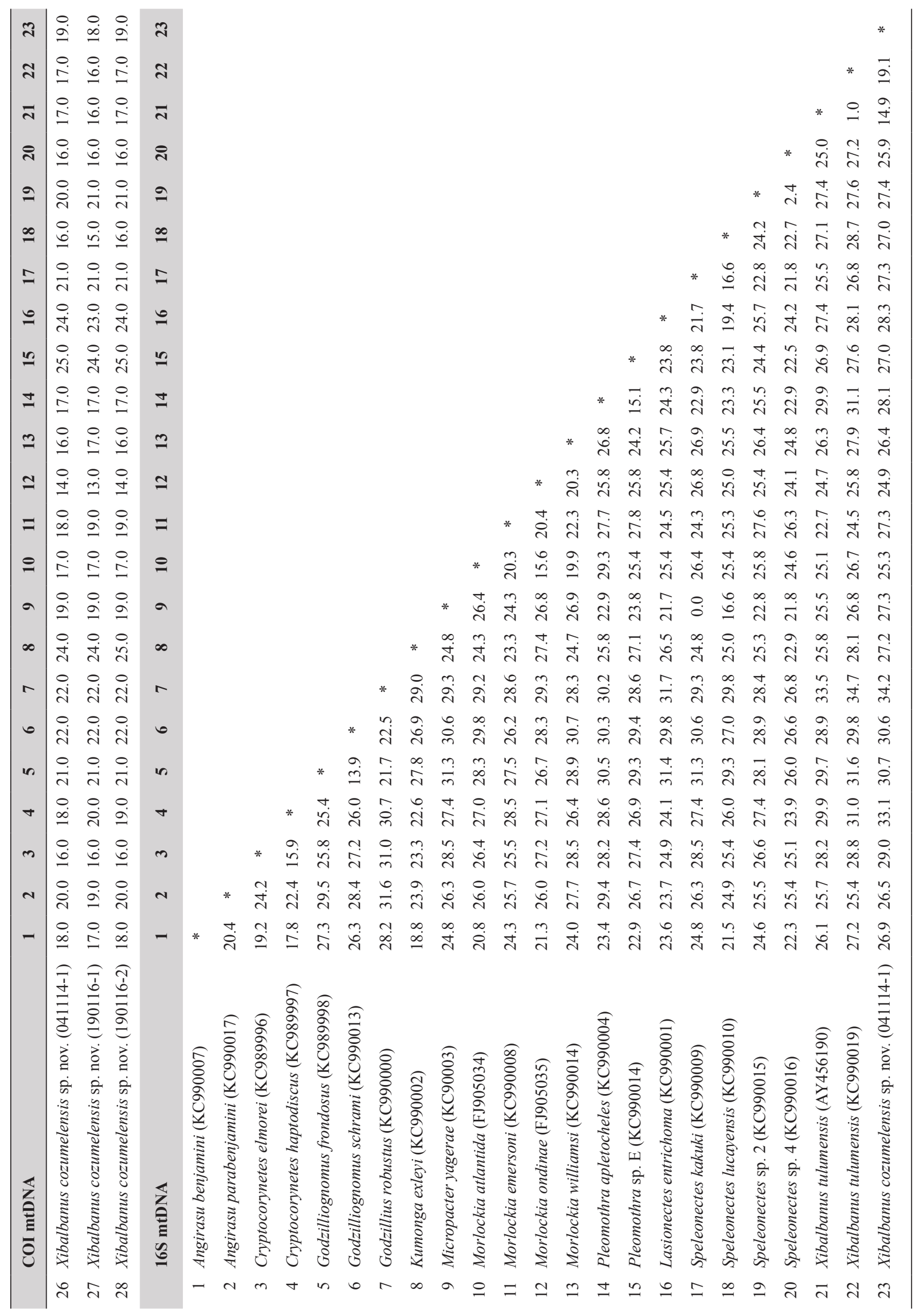




\section{Diagnosis}

Same as for Xibalbanus, see Hoenemann et al. (2013).

\section{Included species}

Xibalbanus tulumensis (Yager, 1987b)

Xibalbanus fuchscockburni (Neiber et al., 2012)

Xibalbanus cokei (Yager, 2013) comb. nov.

Genus Xibalbanus Hoenemann, Neiber, Schram \& Koenemann, 2013

\section{Type species}

Speleonectes tulumensis Yager, 1987.

\section{Diagnosis}

See Hoenemann et al. (2013).

Xibalbanus cozumelensis sp. nov. urn:1sid:zoobank.org:act:B1758E15-23A9-4432-A9D5-DBD10EF11233

Figs $3-10$

Speleonectes sp. - Yañez-Mendoza et al. 2007: 54.

\section{Diagnosis}

Xibalbanus cozumelensis sp. nov. is a slender and comparatively large species (Fig. 3), up to $35 \mathrm{~mm}$ in length; largest specimens with 39 (38 limb-bearing) trunk segments. The species is very similar to Xibalbanus tulumensis (Yager, 1987), but is genetically different from this species and is so far only known from Cozumel.

\section{Etymology}

The specific epithet refers to the type locality of Cozumel.

\section{Material examined}

\section{Holotype}

MEXICO: 33 mm, 39 trunk segments (38 bearing trunk limbs), T. Iliffe and P. Van Hengstum leg., 7 Jul. 2014 (ZMUC-CRU-4791).

\section{Paratypes}

MEXICO: 2 specimens (bearing 37 and 38 trunk limbs respectively), same locality as holotype, part of one individual removed for molecular analysis, other parts dissected for SEM and mounted separately on stubs, T. Iliffe and P. Van Hengstum leg., 7 Jul. 2014 (ZMUC-CRU-4792); 2 specimens, same locality as holotype, T. Iliffe and P. Van Hengstum leg., 3 Jul. 2014 (ZMUC-CRU-4793 and ZMUC-CRU-4794).

\section{Type locality}

MEXICO: Cueva Quebrada, a flooded cave system in Chankannaab National Park on the west coast of Cozumel in Quintana Roo, Mexico at $20^{\circ} 26^{\prime} \mathrm{N}, 86^{\circ} 59^{\prime} \mathrm{W}$ (Fig. 2).

\section{Description}

BoDy. Elongate, without eyes or pigment (Fig. 3). Maximum length of specimens examined $35 \mathrm{~mm}$. The shortest specimen examined is $30 \mathrm{~mm}$. Cephalic shield small, tapering anteriorly with two lateral notches, 
about $1 / 12$ of the total body length; cephalic shield partly covering first trunk segment and proximal parts of cephalic appendages; with distinct transverse suture in the region of maxillae 1, and another transverse but weaker suture in the region of antennae 1 (Figs 3C, 10A). Trunk elongate, maximum number of trunk segments of specimens examined 39 (38 limb bearing). Most trunk segments with similar subrectangular tergites with rounded lateral margins (Fig. 10B); posteriormost segments reduced with posteriorly pointing lateral margins of tergites (Fig. 10I). Appendages are lacking on posteriormost segment (Fig. 4F). Sternal bars very narrow, isomorphic.

FRONTAL FILAMENTS. Long, distally bifurcated into a large anterior branch and a smaller posterior branch (Fig. 5E-F).

Antenna 1 (Figs 3B, 4A, 5B). Two-branched, slender, relatively short, about $1 / 6$ of body length. Protopod 2-segmented; proximal segment is largest with rows of dense, long ribbon-like aesthetascs along median margin; distal segment continues into a long dorsal/lateral branch and a shorter ventral/median branch. Dorsal branch with 11 slender segments most of which have clusters of aesthetascs along medial margin, and small scattered setae, terminal segment with fine terminal setae. Ventral ramus short, less than $1 / 2$ the length of dorsal ramus, 9 segments, basal segments weakly divided, clusters of distomedial aesthetascs and short setae on margins; distal segment with terminal setae.
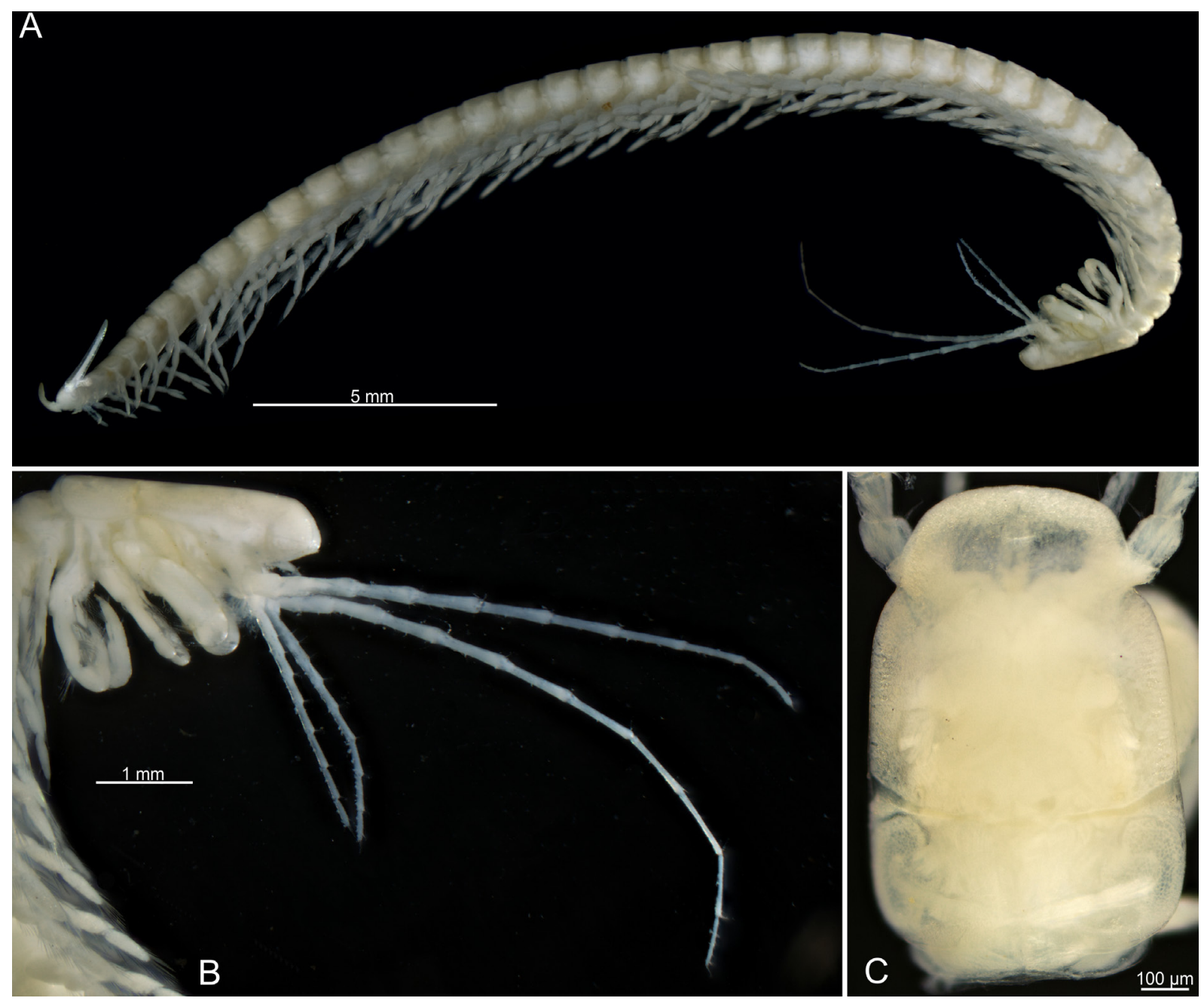

Fig. 3. Xibalbanus cozumelensis sp. nov., light microscopy. A. Holotype, adult specimen, lateral view (ZMUC-CRU-4791). B. Holotype, cephalon, lateral view. C. Paratype, cephalon, dorsal view (ZMUCCRU-4793). 
Antenna 2 (Fig. 4B). A paddle-like biramous appendage. Protopod divided in two segments, a coxa (proximally) and a basis; coxa with 4 medial setae, basis with 9 medial setae. Endopod 3-segmented and curves laterally; segment 1 with 10-11 setae on lateral (outer) margin; segment 2 with 7; segment 3 ovoid, bearing about $27-28$ setae along entire margin, including a terminal double row of about 10 setae. Exopod an unsegmented, large oval plate with about 29-35 setae along margin. All setae plumose with long setules.

LABRUM (Fig. 5E). Prominent, bulbous, subdivided by a transverse suture in an anterior trapezoid shaped part and a posterior (distal) subrectangular part rounded laterally; distally is a dense tuft of fine setae.

MANDiBLes (Fig. 5H-K). Well developed with a gnathal edge consisting of three parts, a molar, a lacinia mobilis, and an incisor; only mandible of left side has been examined in detail. Left molar process occupies approximately $2 / 3$ of the gnathal edge; in apical view the molar is crescent-shaped, composed of a dense row of multi-tipped setules bending towards each other forming a large cavity in the center of the molar; on the functionally anterior side of the molar are clusters of short setules and one cluster of longer. Left incisor broad, flattened, distal margin subdivided into four cusps of subequal morphology (three are pointed, one spade-shaped). The lacinia mobilis is positioned between the incisor and the molar as an extension of the latter, subequal in length to incisor but more narrow terminating in three cusps.

First MAXILla (Figs 4C, 6). 7-segmented, uniramous, robust. Point of flexion between segments 4 and 5. Segment 1 (Fig. 6A-B) relatively short and drawn out medially in a flattened endite with 7 robust setae, posteriormost seta largest, anteriormost serrated; subterminally with row of 4 setules. Segment 2 (Fig. 6A, D) narrow, of subtriangular shape, with elongate, plate-like endite articulated to the segment and directed obliquely medially/anteriorly; terminal margin with one row of 7 robust spines and another more disorganized row of about 17 moderately long or smaller setae; at the posterior margin is a cluster of 4 long setae; at the anterior margin is a row of 5 long setae. Segment 3 (Fig. 6A-B) is trapezoid shaped with a well-developed conical medial endite bearing 2 robust, broad-based cone-shaped setae, each with tiny papilla-like projections on distomedial surface (Fig. 6F, G-I); anteriorly on endite is a row of 5 long, slender setae, posteriorly is 5 setae of different lengths. Segment 4 (Fig. 6A) as large as the three preceding segments, bearing a well-developed conical median endite with 2 large cone-shaped setae as on segment 3 , also with tiny papilla-like projections on distomedial surface; anteriorly on endite is a double-row of 9 setae, posteriorly on endite is a cluster of 9 setae, 4 relatively long and 5 relatively short. Segment 5 (Fig. 6A) about the same length as segment 4 but more slender; cluster of about 12 slender setae in medio-distal corner of segment. Segment 6 (Fig. 6A, C) very short not clearly separated from segment 5 dorsally, with two rows of setae anteriorly and posteriorly, about 8 setae in each. Segment 7 (Fig. 6A-C) short, not clearly separated from segment 6 dorsally, terminating in stout fang-like claw with visible subterminal duct opening, more than 3 times the length of segment 6 ; a cluster of about 6 long simple setae basally at segment 7 .

SeCond MaXiLla (Figs 4D, 7). 7-segmented, uniramous, longer and more slender than maxilla 1; point of flexion between segments 3 and 4; segments 4-7 decreasing in size distally. Segment 1 with 3 digitiform endites (Fig. 7A, D-E) increasing in size anteriorly; all endites with 1 long apical spine-like seta, a row of short, spine-like setae medially (least on endite 1, most in endite 3 ) and a row of long setae laterally (least on endite 1, most in endite 3). Segment 2 (Fig. 7A, F) short, wedge-shaped, 'squeezed in' between segments 1 and 3 with the broad end of the 'wedge' facing medio-anteriorly, medially bearing 1 short, stout, curved medial spine, with a short row of about 4 median setae and short row or cluster of about 5 short to moderately long slender setae at medio-distal corner. Segment 3 (Fig. 7A, F) elongate, rounded medially with row of about 11 long setae and 8 shorter setae. Segment 4 (Fig. 7A) slightly shorter than segment 3, with small distomedial lobe terminating in a cluster of about 10 short to long, thin setae; distolateral corner with 4 slender setae of varying lengths. Segment 5 (Fig. 7A) shorter than segment 4 


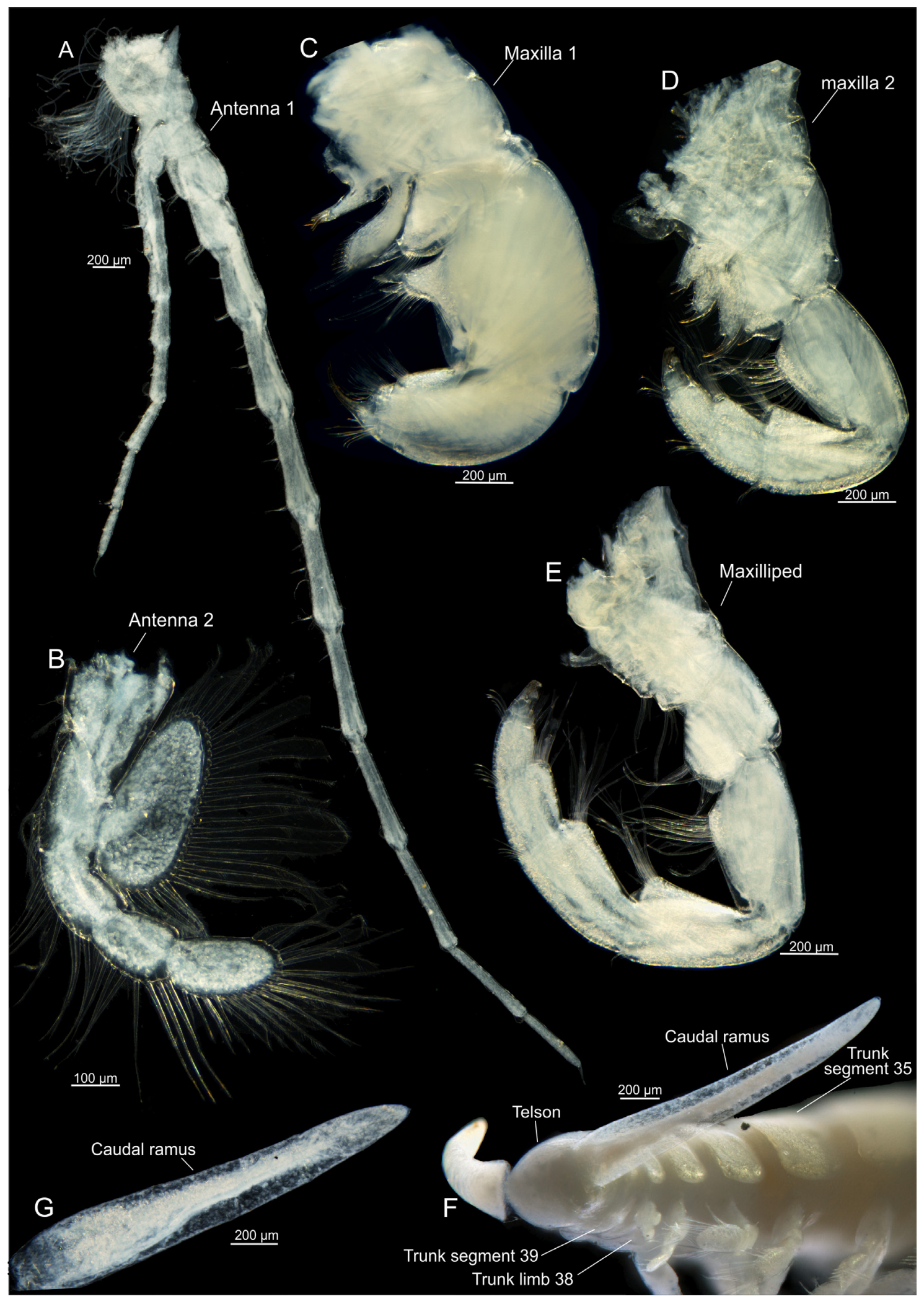

Fig. 4. Xibalbanus cozumelensis sp. nov., holotype (ZMUC-CRU-4791), light microscopy. A. Antenna 1, left side from anterior. B. Antenna 2, left side from anterior. C. Maxilla 1, left side from anterior. D. Maxilla 2, left side from anterior. E. Maxilliped, left side from anterior. F. Caudal rami and posterior part of trunk. G. Caudal ramus, left side seen from median. 


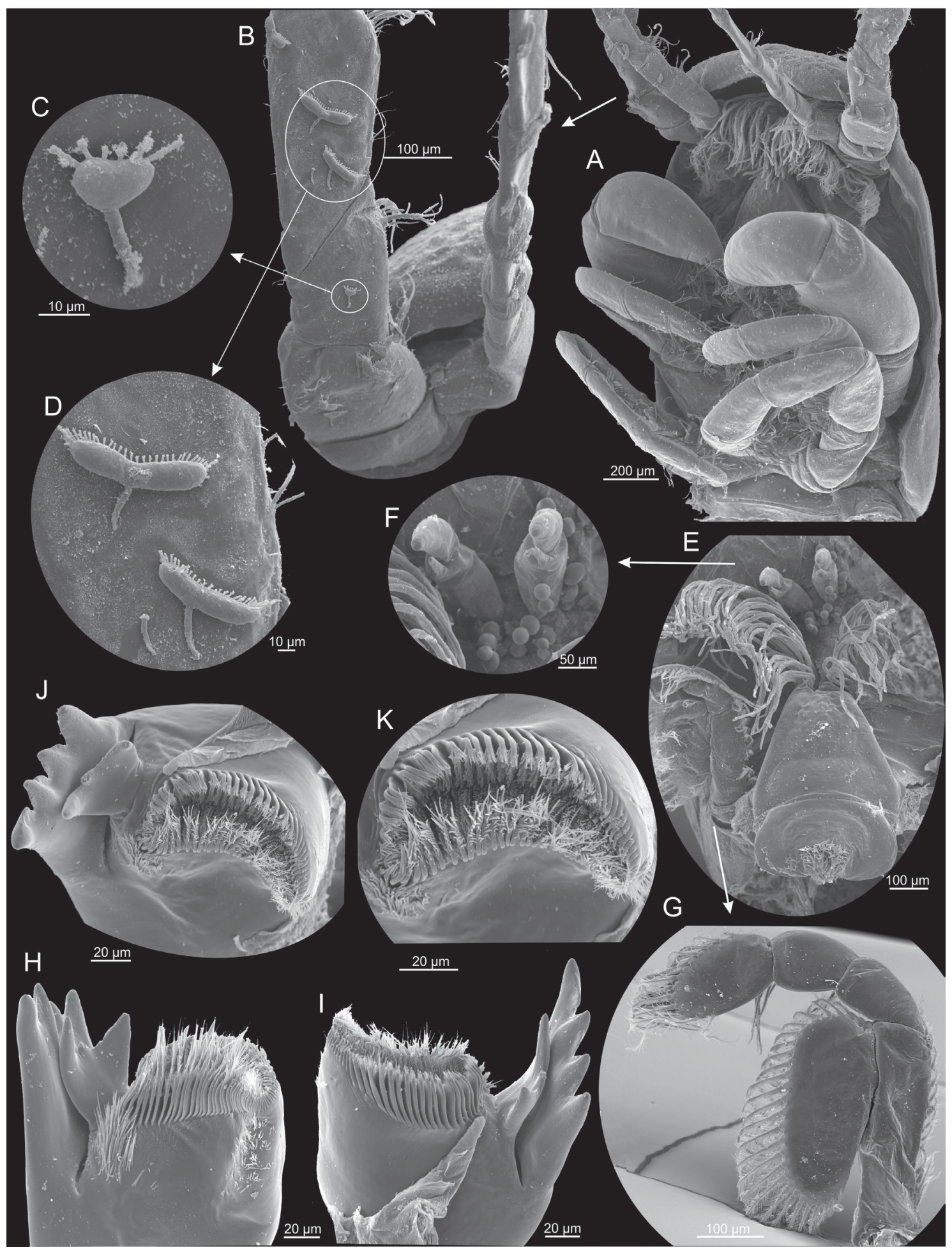

Fig. 5. Xibalbanus cozumelensis sp. nov., paratype (ZMUC-CRU-4792). Cephalon and cephalic structures. Scanning electron microscopy. A. Cephalon with cephalic shield and appendages. B. Antenna 1, right side, proximal parts of dorsal and ventral branches. C-D. Unidentified suctorians attached at the proximo-ventral parts of antenna 1. E. Labrum, frontal filaments, and parts of antennae 1 and 2, right side. F. Frontal filaments. G. Antenna 2, left side from anterior. H. Mandible, left side from anterior. I. Mandible, left side from posterior. J. Mandible, left side, apical view on gnathal edge. K. Mandible, left side, apical view on molar process. 


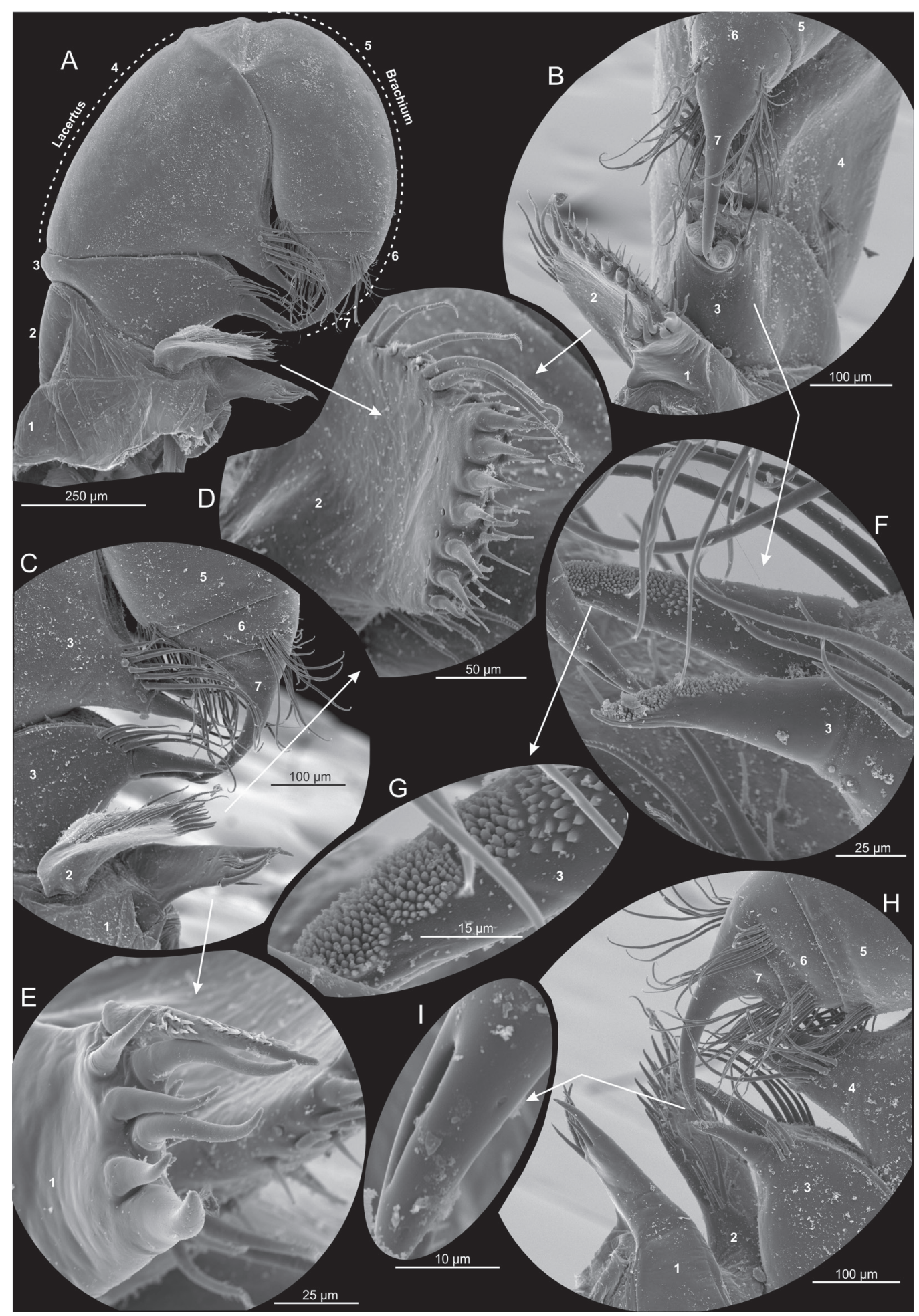

Fig. 6. Xibalbanus cozumelensis sp. nov., paratype (ZMUC-CRU-4792), maxilla 1 (mx1), left side, scanning electron microscopy. A. Complete $m x 1$ from anterior. B. Median view. C. Close-up of median structures (e.g., endites) and distal claw from anterior. D. Distal setation of plate-like endite of segment 2 seen from 'below'. E. Distal setation of endite of segment 1 seen from 'below'. F. Close-up of two robust, broad-based cone-shaped setae of segment 3. G. Close-up of papillae of cone-shaped seta. H. Close-up of median structures (e.g., endites) and distal claw from posterior. I. Fang-like claw with visible subterminal duct opening. 
with approximate same configuration of setae. Segment 6 (Fig. 7A, F) bearing a large cluster of about 15 setae at distomedial corner and a pair of clusters at the disto-lateral corners (about 6 setae in each). Segment 7 (Fig. 7A, C) very short, about half the length of segment 6, with terminal claw complex consisting of fused arch of at least 17 denticles and 1 long, stout anterior spine; 1 short, stout anterior spine subterminal to fused arch; opposable thumb-like pad bearing many (at least 40) setae which fan under claw complex.

MAXILliped (Figs 4E, 8). 8-segmented, generally similar in shape but longer and more slender than maxilla 2, with one more segment beyond point of flexure. Segment 1 (Fig. 8A, C) is short with 5 long and 2 short setae along median margin and about 3-4 small setae in a row more proximally. Segment 2 is large and undivided in anterior view (Fig. 8A), but in posterior view it is subdivided by an oblique furrow giving the appearance of two separate triangular segments (Fig. 8C); at the medio-distal margin is a row of 12 setae of varying length. Segment 3 as long as the combined length of segments 1-2; with round medial margin with about 15 slender setae of varying length in a dense row in the middle of the segment. Segment 4 (Fig. 8A, C) the same length as segment 3, subtriangular in shape, with a cluster of about 15 setae of varying size at disto-medial corner, and a small cluster of about 4 short setae in latero-distal corner. Segment 5 (Fig. 8A, C) approximately the same size as segment 4 but more rectangular; about 12 setae in a cluster at disto-medial corner, 5 in latero-distal corner. Segment 6 (Fig. 8A, C) very similar to segment 5 with respect to setation, but only slightly more than half as long. Segment 7 (Fig. 8A, C) about the same length as segment 6 with rows of short setae along distal margin of segment: two rows at the disto-lateral corners of the anterior and posterior side of segment, each with 4-6 setae, and two rows at the disto-medial corners with about 10 (anterior side) or 5 (posterior side) setae. Segment 8 (Fig. 8B, D) similar to claw complex on maxilla 2, with stout anterior spine subterminal to arched claw complex and with opposable setae-bearing pad.

TRUNK. Limbs biramous (Figs 9-10), natatory, with large protopod, 4-segmented endopod and 3 -segmented exopod; long plumose setae along margins; size of limbs varies along body, increasing in size from trunk limb 1 to approximately trunk limb 7, decreasing in size approximately from trunk limb 29 onwards; trunk limbs 37 and 38 are significantly reduced in size (Fig. 4F); in the most anterior trunk limbs the exopod is longer than the endopod, in the middle range of trunk limbs the rami are sub-equal in size, around trunk limb 30 onwards the endopod is clearly larger, while in the last two reduced trunk limbs (37 and 38) the exopods are largest (Fig. 9).

Caudal Rami. Very slender, about 4-5 times length of anal segment with small terminal setae (Figs $4 \mathrm{~F}-\mathrm{G}, 10 \mathrm{H}-\mathrm{I})$.

\section{Remarks}

Unidentified suctorians of varying shapes were found attached at the proximo-ventral parts of antennae 1 and at the trunk limbs (Figs 5C-D, 10F-G).

\section{Remipedia CO1 and 16S mtDNA distance matrices}

Table 2 shows uncorrected genetic distances of $\mathrm{CO} 1$ and 16S mtDNA among populations of Xibalbanus cozumelensis sp. nov. obtained in this study and other Remipedia of which data are available in GenBank (see also Neiber et al. 2012; Hoenemann et al. 2013). The CO1 gene was sequenced for three specimens of $X$. cozumelensis sp. nov. yielding a 0-3\% pairwise genetic distance between the individuals. The $X$. cozumelensis specimens are genetically (CO1) closest to populations of $X$. tulumensis from the 'mainland' Yucatán Peninsula with a 9-11\% genetic distance. The genetic distance between $X$. cozumelensis and other remipedes varies between $13 \%$ and $25 \%$. The genetic distance (CO1) among species of Remipedia in general varies between $12 \%$ and $31 \%$, but only with few values in the low end of the spectrum, e.g., the distance between two species of Cryptocorynetes (C. longulus Wollermann, 


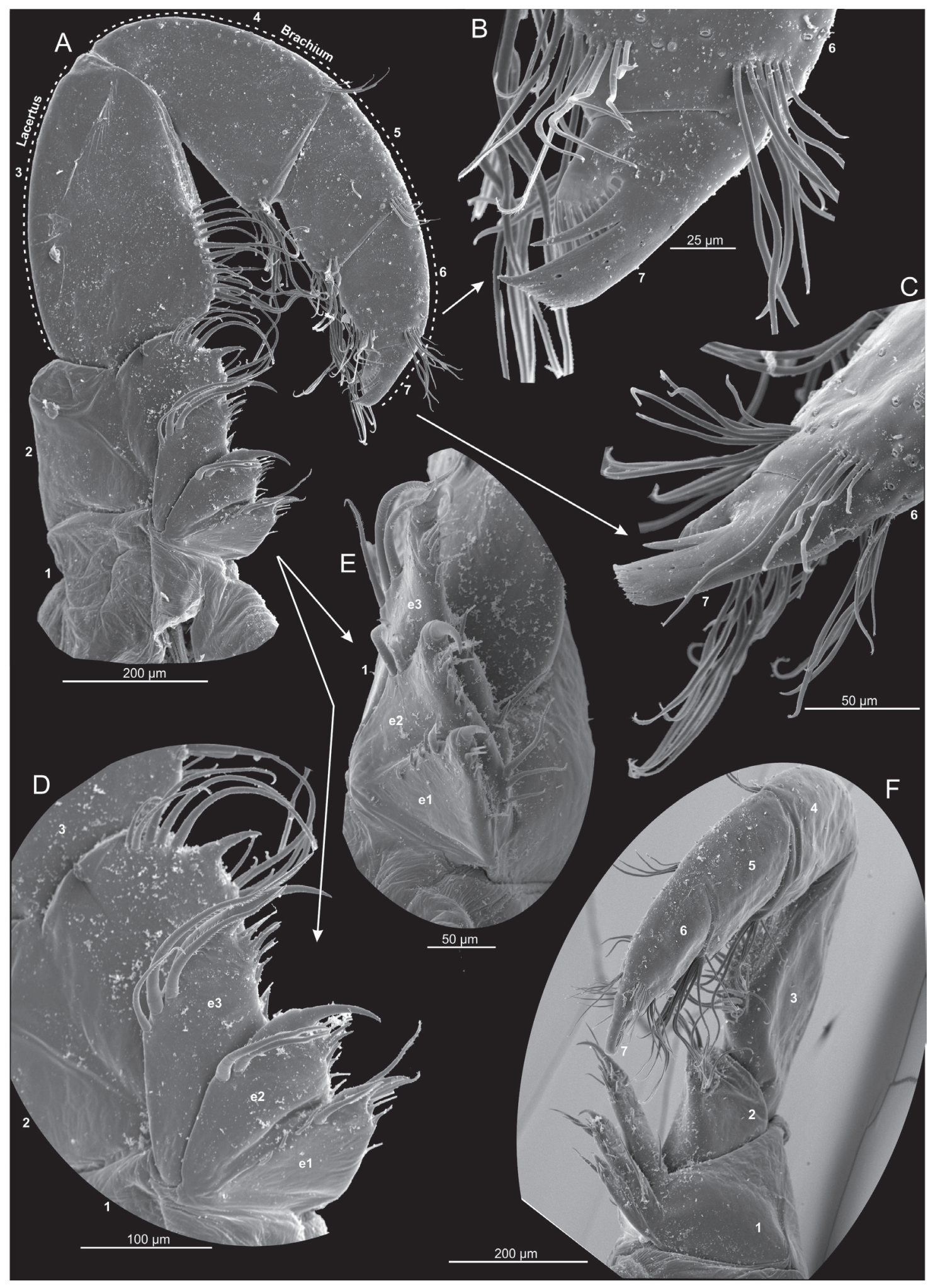

Fig. 7. Xibalbanus cozumelensis sp. nov., paratype (ZMUC-CRU-4792), maxilla 2 (mx2), left side, scanning electron microscopy. A. Complete $\mathrm{mx} 2$ from anterior. B. Close-up of terminal claw-complex from anterior (segment 7). C. Close-up of terminal claw-complex from lateral (segment 7). D. Median side of segments 1 and 2 with endites (e1-3) from anterior. E. Endites of segment 1 (e1-3) from median. F. Complete $\mathrm{mx} 2$ from median. 


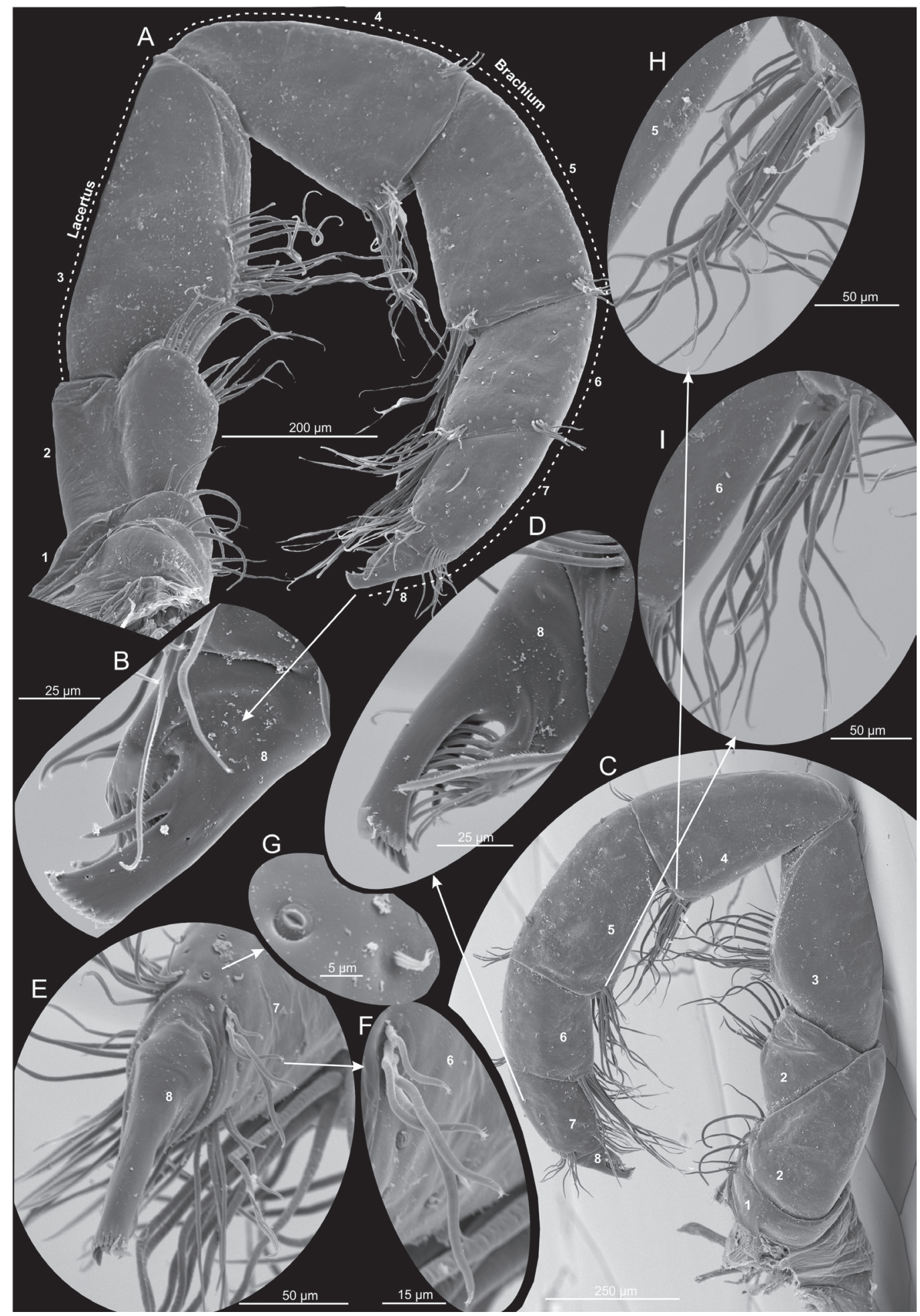

Fig. 8. Xibalbanus cozumelensis sp. nov., paratype (ZMUC-CRU-4792), maxilliped (mxp), left side, scanning electron microscopy. A. Complete mxp from anterior. B. Close-up of terminal claw-complex from anterior (segment 8). C. Complete mxp from posterior. D. Close-up of terminal claw-complex from posterior (segment 8). E. Close-up of terminal claw-complex from lateral (segment 8). F. Close-up of small cluster of setae along distal margin of segment 7. G. Close-up of pore at close to latero-distal margin of segment 7. H. Close-up of cluster of setae at latero-distal corner of segment 4. I. Close-up of cluster of setae at latero-distal corner of segment 5 . 
Koenemann \& Iliffe, 2007 and C. haptodiscus Yager, 1987) and two species of Godzillius (G. fuchsi Gonzalez, Singpiel \& Schlagner, 2013 and G. robustus Schram, Yager \& Emerson, 1986), which are $13 \%$, and the distances between two species of Morlockia (M. ondinae García-Valdecasas, 1984 and M. atlantida (Koenemann et al., 2009)), which is $12 \%$. The rest of the CO1 genetic distances between species of Remipedia based on sequences available in GenBank are included for completeness but will not be described further here (Table 2). 16S was sequenced for one specimen of X. cozumelensis sp. nov. The specimen is genetically (16S) closest to $X$. tulumensis showing genetic distances of $14-19 \%$. The genetic distances in the $16 \mathrm{~S}$ gene between species of Remipedia generally are between $20-30 \%$, but with the distance between a few species being lower and at the same level as between $X$. cozumelensis sp. nov. and X. tulumensis (e.g., Cryptocorynetes haptodiscus and C. elmorei Hazerli, Koenemann \&

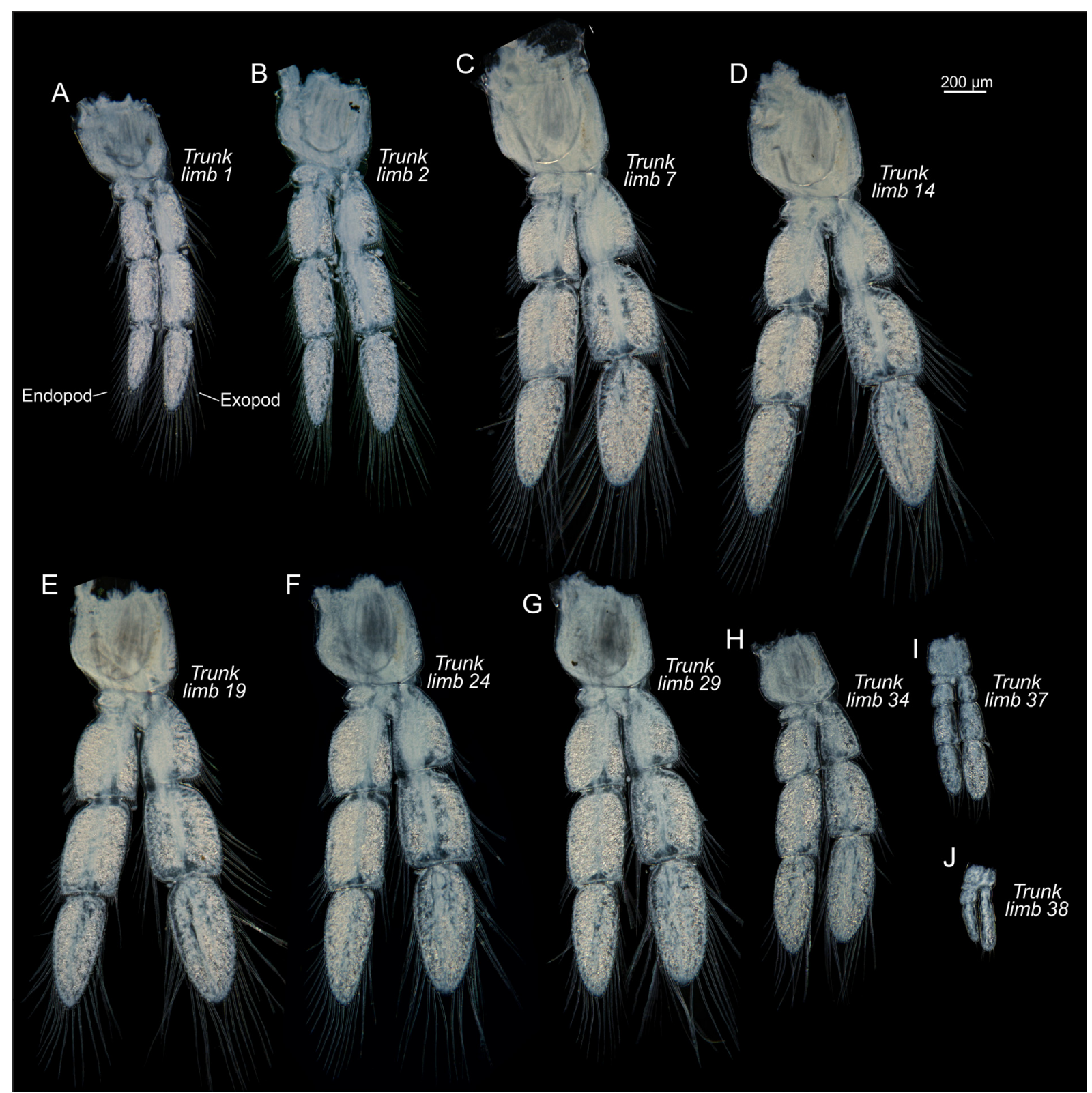

Fig. 9. Xibalbanus cozumelensis sp. nov., holotype (ZMUC-CRU-4791), trunk limbs, left side from anterior, light microscopy. A-J. Selected trunk segments (number specified on figure). All to the same scale. 
Iliffe, 2009 at 16\%, and Speleonectes lucayensis Yager, 1981 and S. kakuki Daenekas, Iliffe, Yager \& Koenemann, 2009 at 17\%). CytB was compared to CytB extracted from the complete mitochondrion of $X$. tulumensis (AY456190). The $X$. cozumelensis sp. nov. sequences were identical and had a $15 \%$ genetic distance from $X$. tulumensis.

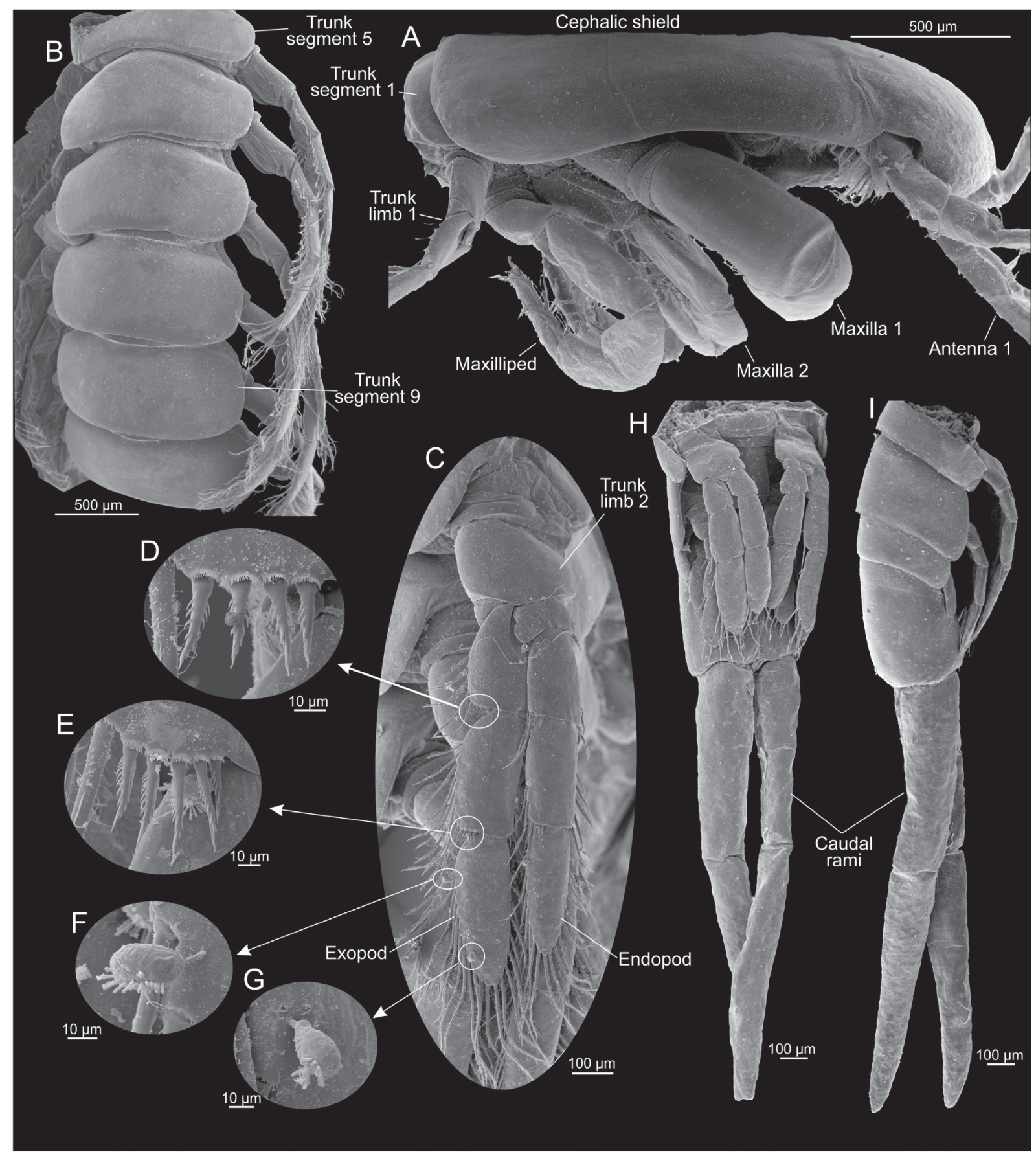

Fig. 10. Xibalbanus cozumelensis sp. nov., paratype (ZMUC-CRU-4792), cephalon, body segments, and trunk limbs, scanning electron microscopy. A. Cephalon, cephalic shield, and head appendages from lateral. B. Trunk segments 5-10. C. Trunk limb 2, right side. D. Close-up of serrated setae in latero-distal corner of exopod segment 1. E. Close-up of serrated setae in latero-distal corner of exopod segment 2. F-G. Two unidentified suctorians attached to exopod of trunk limb 3. H-I. Posterior body segments, trunk limbs, and caudal rami from ventral and lateral. 


\section{Phylogeny of Remipedia based on Bayesian analysis of CO1 and 16S mtDNA genes}

The phylogenetic tree of Remipedia in Fig. 11 is based on a Bayesian analysis of the CO1 and 16S mtDNA genes. New sequences of both $\mathrm{CO} 1$ and $16 \mathrm{~S}$ have been obtained for Xibalbanus cozumelensis sp. nov. Sequences from other species of Remipedia are from GenBank and were previously used in Neiber et al. (2012) and Hoenemann et al. (2013). In the phylogeny (Fig. 11) all included species of Xibalbanus were in the same clade (monophyletic). Xibalbanus cozumelensis sp. nov. appeared as sister species to X. tulumensis, and these two together appeared as sister of X. fuchscockburni. The remaining part of the phylogeny was largely similar to the topology obtained by Hoenemann et al. (2013) and is not further described here as the focus was on Xibalbanus.

\section{Discussion}

\section{Xibalbanus and morphological affinities of $X$. cozumelensis sp. nov.}

The remipede genus Xibalbanus, recognized primarily on the basis of molecular data, was established by Hoenemann et al. (2013) with a morphological diagnosis of the genus provided in the same paper. Two remipede species were included in the genus, both from the Yucatán Peninsula. At approximately the same time an additional remipede species was described from a sub-seafloor cave in Belize, nearly $300 \mathrm{~km}$ to the south of the two Yucatán species of Xibalbanus. No molecular data are yet available for this species, but morphologically it falls within the Xibalbanus diagnosis as provided by Hoenemann et al. (2013) and should therefore be recognized as Xibalbanus cokei (Yager, 2013).

Here, we describe a fourth species in the genus, Xibalbanus cozumelensis sp. nov. from an anchialine cave on the island of Cozumel that is separated $18 \mathrm{~km}$ to the east of the Yucatán Peninsula by the $\sim 400$ m-deep Cozumel Channel.

The generic affinity of Xibalbanus cozumelensis sp. nov. is clear as it has all the diagnostic characters mentioned for Xibalbanus by Hoenemann et al. (2013), such as the same shape of the frontal filaments, distinctly longer maxillipeds than maxillae 2 , very long caudal rami, and more than 30 trunk segments in adults (see Hoenemann et al. 2013). Within the genus Xibalbanus, X. cozumelensis sp. nov. is most different from $X$. cokei (see Table 3), e.g., in having 11 segments in the dorsal ramus of antenna 1 (vs 12 in X. cokei), a less setose exopod of antenna 2, a slightly more compact and less setose maxilla 2, and a less setose maxilliped. Xibalbanus cozumelensis sp. nov. is also distinctly different from Xibalbanus fuchscockburni (Neiber et al. 2012) from which it differs in having more segments in the ventral first antenna ramus (9 vs 5-6), more setose exopod of antenna 2, maxilla 2 more setose in general, e.g., longer setae row on medial side of lacertus, maxilliped more setose in general. Xibalbanus cozumelensis sp. nov. is most similar to Xibalbanus tulumensis (Cenote Carwash population), and the two species are practically indistinguishable morphologically, except for minor differences in the exact number of setae on various parts of the limbs (antenna 2, maxilla 1, maxilla 2, maxilliped), but which showed no consistent pattern when comparing the two species. Hence, the basis for recognizing $X$. cozumelensis sp. nov. as a separate species rests mainly on its genetic distance from the Xibalbanus species of 'mainland' Yucatán, which likely developed from its geographic isolation (discussed further below).

\section{Genetic distance and phylogenetic position of Xibalbanus cozumelensis sp. nov.}

Both partial CO1 and 16S rDNA genes of Xibalbanus cozumelensis sp. nov. were sequenced in this study and compared with information for other remipede species compiled in part by Neiber et al. (2012) and available in GenBank (Table 2, Fig. 11). For both genes Xibalbanus cozumelensis sp. nov. is closest to populations of $X$. tulumensis (Table 2). The uncorrected genetic distance of CO1 between $X$. cozumelensis sp. nov. and $X$. tulumensis is about $10 \%$. This is slightly smaller than the distance of $12 \%$ between Morlockia ondinae and $M$. atlantida, two sympatrically occurring species from the Canarian 


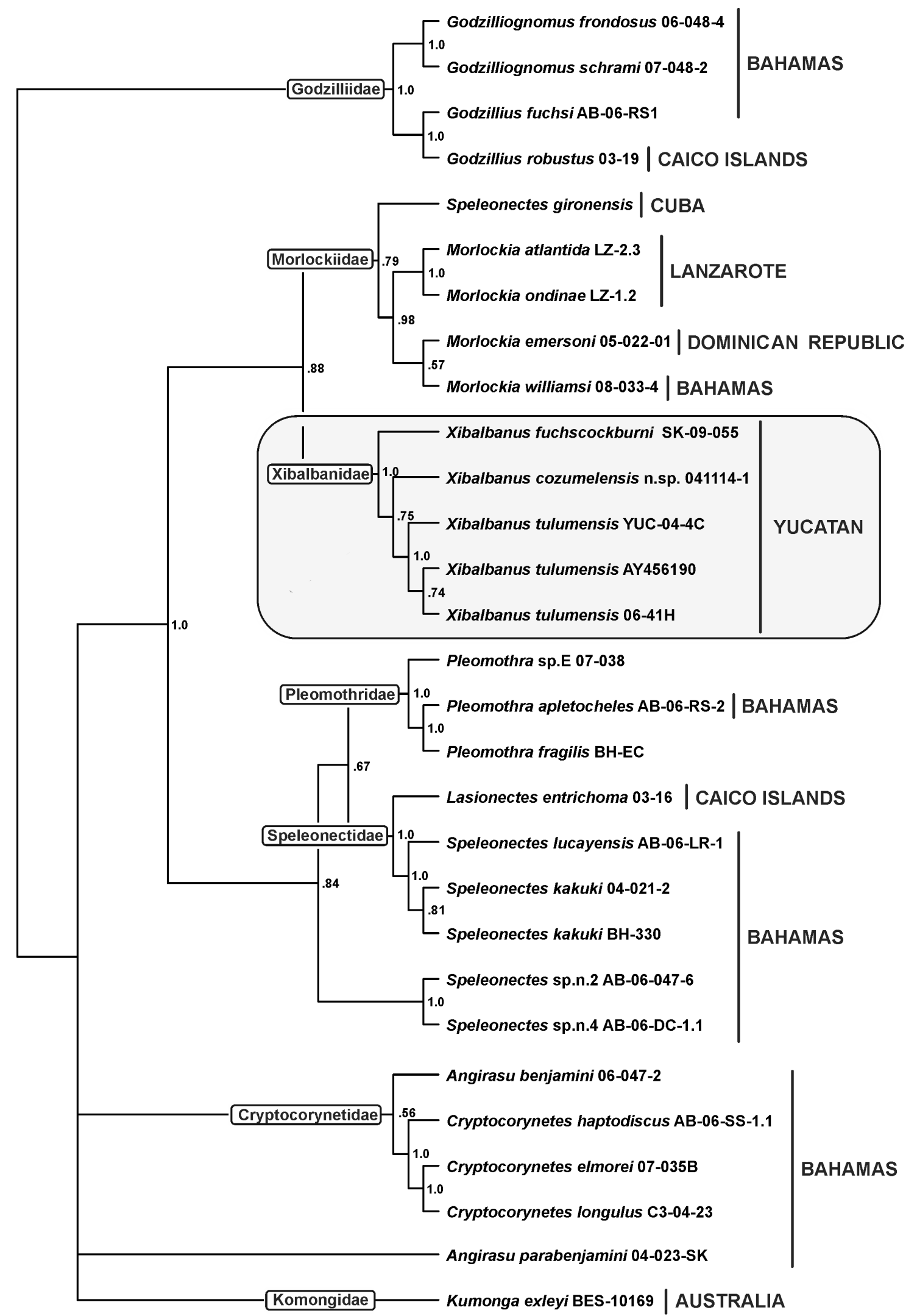

Fig. 11. Phylogenetic position of Xibalbanus cozumelensis sp. nov. based on a Bayesian analysis of partial CO1 and 16S rDNA sequences of $X$. cozumelensis sp. nov. and other remipedes available from GenBank. 
Table 3. Morphological comparisons among species of Xibalbanus from Yucatán, Belize, and Cozumel. Based on information presented here and from literature (Yager 1987, 2013; Neiber et al. 2012).

\begin{tabular}{lcccc}
\hline & $\begin{array}{c}\text { X. cokei } \\
\text { comb. nov. }\end{array}$ & X. tulumensis & X. fuchscockburni & $\begin{array}{c}\text { X. cozumelensis } \\
\text { sp. nov. }\end{array}$ \\
\hline Antenna 1, dorsal ramus segments & 12 & 11 & $11-12$ & 11 \\
Antenna 2, exopod setal count & 58 & 32 & 17 & $29-35$ \\
Maxilla 1, segment 2, spines on plate- & $9-10$ & $6-8$ & $9 ?$ & 7 \\
like endite & & & & $10-12$ \\
Maxilla 2, denticles on claw complex & 17 & 16 & $3 \times$ & $13-14$ \\
Caudal rami to anal segment length & $5 \times$ & $4 \times$ & & $4 \times-5 \times$ \\
\hline
\end{tabular}

Island of Lanzarote, but still significantly larger than the intraspecific genetic distance of $\sim 0.5 \%$ within five remipede species reported by Koenemann et al. (2009), and, even more importantly, larger than the genetic distance between various populations of $X$. tulumensis ranging from $0.4 \%$ to $1.2 \%$ (Neiber et al. 2012) (see also Table 2). The intraspecific genetic distance within $X$. cozumelensis based on three individuals examined in this study varied between 0-3\% (Table 2). Also with respect to the $16 \mathrm{~S}$ gene, $X$. cozumelensis sp. nov. is closest to populations of $X$. tulumensis with a distance between $15 \%$ and $19 \%$, but the differences are still high compared to the intraspecific genetic distance between the two included populations of $X$. tulumensis, which is about $1 \%$ (Table 2).

Thus far, only a limited number of Xibalbanus populations from the Yucatán 'mainland' have been sequenced for $\mathrm{CO} 1$ and/or 16S, which includes the more northern population from Cenote Crustacea (near Puerto Morelos), and populations from the more southern locality of Cenote Mayan Blue. Unfortunately, specimens from the type locality of X. tulumensis, Cenote Carwash, have not been sequenced. Considering that the differences between species of Xibalbanus are very small, both morphologically and molecularly (Neiber et al. 2012; this work), it will be of great importance in future work on remipede diversity at the Yucatán Peninsula to routinely include sequencing of the CO1 gene. Xibalbanus cf. tulumensis has been reported from a variety of localities from the 'mainland' Yucatán Peninsula (Fig. 2, Table 4), but sequencing will likely be necessary to ascertain their precise affinity to currently described remipede taxa. Indeed, a broader work on remipede diversity of the Yucatán Peninsula, with a focus on the molecular variation, would be important not only for species recognition, but would also help to determine the degree of gene flow among various cave systems, and possibly provide insight into the genetic connectivity of populations.

In order to analyze the phylogenetic relationship of $X$. cozumelensis sp. nov., we added the newly generated CO1 and 16S sequences to a matrix containing comparable data available from GenBank ${ }^{\circledR}$ for most remipedes. Parsimony analysis provides evidence for the monophyly of the genus Xibalbanus and $X$. cozumelensis sp. nov. as a member of this genus, more specifically as sister to X. tulumensis, with X. fuchscockburni as the sister to these two species (Fig. 11). As a part of the analysis of Xibalbanus, the general phylogeny of the Remipedia was re-analyzed, but since it was based mainly on the same data as used in Hoenemann et al. (2013), the result is largely the same so only a few comments will be given here. First of all it should be noted that Hoenemann et al. (2013) did not resolve the family affiliation of Xibalbanus, which has here been placed in its own family: Xibalbanidae fam. nov. (Fig. 11). Another question left unresolved by Hoenemann et al. (2013) was the taxonomic status of Speleonectes gironensis Yager, 1994. In the phylogeny based CO1 and 16S data shown in Fig. 11, S. gironensis is placed separately from the other species of Speleonectes (S. kakuki and S. lucayensis) as sister to the 
Table 4. Localities of Xibalbanus on the Yucatán Peninsula, including Belize and Cozumel reported in literature or observed by T.M. Iliffe. Several other sites from mainland Yucatán have been reported by non-biologist cave divers, but as stygiomysids can easily be mistaken for remipedes in the field, only published reports or personal observations have been included in the table. The localities from which $\mathrm{CO} 1 \mathrm{and} /$ or $16 \mathrm{~S}$ has been sequenced and used/reused in this work are underlined (see listed references for more details).

\begin{tabular}{|c|c|c|}
\hline Species & Known localities & References \\
\hline $\begin{array}{l}\text { X. cozumelensis } \\
\text { sp. nov. }\end{array}$ & COZUMEL: $\underline{\text { Cueva Quebrada }}$ & $\begin{array}{l}\text { Yañez-Mendoza et al. (2007); } \\
\text { this work }\end{array}$ \\
\hline $\begin{array}{l}X . \text { tulumensis } \\
\text { (Yager, 1987) }\end{array}$ & $\begin{array}{l}\text { YUCATÁN: Cenote Crustacea, Cenote Chac Mool, } \\
\text { Cenote Ponderosa (Cenote Jardín del Edén), Cenote } \\
\text { Tajma Ha, Cenote Carwash (Cenote Aktun Ha), Cenote } \\
\text { Vaca Ha, Cenote Temple of Doom (Cenote Calavera, } \\
\text { Cenote Esqueleto), Cenote Najaron, Cenote Maya Blue } \\
\text { (Cenote Escondido), Cenote Bang, Cenote Muknal, } \\
\text { Cenote Odyssey }\end{array}$ & $\begin{array}{l}\text { Alvarez et al. (2015); } \\
\text { Hoenemann et al. (2013); Neiber } \\
\text { et al. (2011, 2012); Yager (1987) }\end{array}$ \\
\hline
\end{tabular}

X. fuchscockburni YUCATÁN: Cenote Crustacea (Neiber et al., 2012)

X. cokei (Yager, BELIZE: Caye Chapel Cave Neiber et al. (2012) 2013) comb. nov.

Yager (2013)

genus Morlockia. These disparate positions of species of Speleonectes in the phylogeny could suggest that $S$. gironensis either should be treated as a member of Morlockia or that it deserves to be treated as a separate new genus, but, as did Hoenemann et al. (2013), we leave the question open for now. Another difference between Hoenemann et al. (2013) and the present work concerns Micropacter yagerae Koenemann, Iliffe \& van der Ham, 2007, placed in the monotypic family Micropacteridae. Based on a combined analysis of several loci, Hoenemann et al. (2013) found M. yagerae to be the sister to all other remipedes, which suggests a significant phylogenetic importance of this species. However, in this study we did not include sequences of M. yagerae because its CO1 sequence is not available in GenBank ${ }^{\circledR}$ (not sequenced by Hoenemann et al. 2013), and because the available 16S sequence in GenBank ${ }^{\circledR}$ is dubious as it is identical to that of Speleonectes kakuki. Hence, despite the intrinsic classification of Remipedia having been much clarified by Hoenemann et al. (2013), a number of aspects need more study, preferably based on a larger molecular dataset. But this was beyond the scope of the present work, which focused on the taxonomy of Xibalbanus.

\section{Zoogeographical relationship between Cozumel and Yucatán remipedes}

Given the relatively low genetic distance between Xibalbanus tulumensis and X. cozumelensis sp. nov., it is worth considering possible drivers of speciation between these two closely related species. On a global scale, it is generally accepted that the highly disjunctive biogeography of modern remipedes, with populations from opposite sides of the Atlantic and from the eastern Indian Ocean, provides evidence that remipedes do not experience oceanic dispersal as part of their current life cycle, and therefore vicariance is a primary driver of speciation and their biogeography. The results provided here show that two different remipede species reside on geographically proximal landmasses, naturally lending speculation to the potential regional tectonic, geologic, or sea-level drivers of a possible allopatric speciation event. 
It is generally thought that Cozumel and the Arrowsmith Bank are part of a horst block that is bounded by normal faults trending to the northeast as part of the Rio Hondo Fault Zone (Uchupi 1973; Spaw 1978; Weidie 1989). Movement along these faults likely began in the Cretaceous (late Mesozoic), and likely persisted through the early Cenozoic (Dillon \& Vedder 1973; Ward 1997), resulting in a probable separation of Cozumel from mainland Yucatán by the early Cenozoic ( $\sim 65 \mathrm{Ma})$. It is possible that the geologic separation of Cozumel from mainland Yucatán provided the geographic isolation necessary for allopatric speciation. However, this scenario then implies a very low divergence rate of $\sim 0.15 \%$ per million years for the CO1, which is far less than the rate found for arthropods such as several species of snapping shrimps using the formation of the Isthmus of Panama as a reference for dating (Knowlton et al. 1993; Knowlton \& Weigt 1998). Perhaps though in environmentally stable environments such as anchialine caves, lower rates of divergence are possible. An alternative hypothesis would argue for a much more recent speciation event between Xibalbanus tulumensis and X. cozumelensis when Pleistocene glacial sea level was about $120 \mathrm{~m}$ lower. Given that the Cozumel Channel is $400 \mathrm{~m}$ deep, seawater still would have separated Cozumel from the mainland Yucatán Peninsula during such late Pleistocene sea level oscillations. An eventual more recent migration of remipedes between the mainland Yucatán Peninsula and Cozumel may have been possible through subsurface macroporosity (e.g., caves or crevices) beneath the Yucatán Channel. However, since all known caves currently inhabited by remipedes are significantly less than $120 \mathrm{~m}$ deep and thus were dry during low sea stands of the Pleistocene, as is evidenced by the presence of submerged speleothems, remipedes must have undergone significant vertical and likely horizontal dispersal as glacial sea level receded. Whether such requisite subsea floor crevices actually underlie the Cozumel Channel remains to be seen. Thus, until a better understanding of modern biogeography, regional geology and additional genetic analysis for comparison between remipede populations becomes available, it will not be possible to fully resolve this question.

\section{Acknowledgements}

We express our gratitude to Germán Yañez of Yucatech Expeditions for providing logistic assistance and acting as our cave diving guide in Cozumel. A collecting permit for Remipedia was issued by SEMARNAT (Secretaría de Medio Ambiente y Recursos Naturales) to Thomas M. Iliffe via a permit to Dr. Fernando Álvarez (FAUT-0104). This study was partially supported by a Texas A\&M University - CONACYT collaborative science grant \#10655 (T. Iliffe and F. Álvarez) and a NSF award (to PvH, OCE-1356509). JO was supported by a grant from the Danish Agency for Science, Technology and Innovation (0601-12345B). Frederick R. Schram and Marco T. Neiber are thanked for helpful comments to an earlier version of the manuscript.

\section{References}

Alvarez F., Iliffe T.M., Benitez S., Brankovits D. \& Villalobos J.L. 2015. New records of anchialine fauna from the Yucatan Peninsula, Mexico. Check List 11: 1-10. https://doi.org/10.15560/11.1.1505

Carpenter J.H. 1999. Behavior and ecology of Speleonectes epilimnius (Remipedia, Speleonectidae) from surface water of an anchialine cave on San Salvador Island, Bahamas. Crustaceana 72 (8): 979 991. https://doi.org/10.1163/156854099503889

Chávez G., Candela J. \& Ochoa J. 2003. Subinertial flows and transports in Cozumel Channel. Journal of Geophysical Research 108: 1-11. https://doi.org/10.1029/2002JC001456

Daenekas J., Iliffe T.M, Yager J. \& Koenemann S. 2009. Speleonectes kakuki, a new species of Remipedia (Crustacea) from anchialine and sub-seafloor caves on Andros and Cat Island, Bahamas. Zootaxa 2016: 51-66. https://doi.org/10.15468/c8ooey

Dillon W.P. \& Vedder J.G. 1973, Structure and development of the continental margin of British Honduras. Geological Society of America Bulletin 84: 2713-2732. 
OLESEN J. et al., A new species of Remipedia and phylogeny of Xibalbanus from Mexico

Edgecombe G.D., Richter S. \& Wilson G.D.F. 2003. The mandibular gnathal edges: Homologous structures throughout Mandibulata? African Invertebrates 44: 115-135.

Ertas B., Reumont B.M. von, Wägele J.-W., Misof B. \& Burmester T. 2009. Hemocyanin suggests a close relationship of Remipedia and Hexapoda. Molecular Biology and Evolution 26 (12): 2711-2718.

Hengstum P.J. van \& Scott D.B. 2011. Ecology of foraminifera and habitat variability in an underwater cave: distinguishing anchialine versus submarine cave environments. Journal of Foraminiferal Research 41 (3): 201-229. https://doi.org/10.2113/gsifr.41.3.201

Hoenemann M., Neiber M.T., Koenemann S., Humphreys W.F., Iliffe T.M., Li D., Schram F.R. \& Koenemann S. 2013. Phylogenetic analysis and systematic revision of Remipedia (Nectiopoda) from Bayesian analysis of molecular data. Journal of Crustacean Biology 33: 603-619. https://doi. org/10.1163/1937240X-00002179

Koenemann S., Iliffe T. \& Ham J. van der. 2003. Three new sympatric species of Remipedia (Crustacea) from Great Exuma Island, Bahamas Islands. Contributions to Zoology 72: 227-252.

Koenemann S., Schram F.R. \& Iliffe T.M. 2006. Trunk segmentation patterns in Remipedia. Crustaceana 79: 607-631. https://doi.org/10.1163/156854006777584296

Koenemann S., Bloechl A., Martínez A., Iliffe T.M., Hoenemann M. \& Oromí P. 2009. A new, disjunct species of Speleonectes (Remipedia, Crustacea) from the Canary Islands. Marine Biodiversity 39: 215225. https://doi.org/10.1007/s12526-009-0021-8

Knowlton N. \& Weigt L.A. 1998. New dates and new rates for divergence across the Isthmus of Panama. Proceedings of the Royal Society B 265: 2257-2263. https://doi.org/10.1098/rspb.1998.0568

Knowlton N., Weigt L.A., Solórzano L.A., Mills D.K. \& Bermingham E. 1993. Divergence in proteins, mitochondrial DNA and reproductive compatibility across the Isthmus of Panama. Science 260: 16291632.

Merrit T.J.S., Shi L., Chase M.C., Rex M.A., Etter R.J, Quattro J. M. 1998. Universal cytochrome b primers facilitate intraspecific studies in molluscan taxa. Molecular Marine Biology and Biotechnology 7 (1): 7-11.

Neiber M.T., Hartke T.R., Stemme T., Bergmann A., Rust J., Iliffe T.M. \& Koenemann S. 2011. Global biodiversity and phylogenetic evaluation of Remipedia (Crustacea). PLOS ONE 6: 1-12. https://doi. org/10.1371/journal.pone.0019627

Neiber M.T., Hansen F.C., Iliffe T.M., Gonzalez B.C. \& Koenemann S. 2012. Molecular taxonomy of Speleonectes fuchscockburni, a new pseudocryptic species of Remipedia (Crustacea) from an anchialine cave system on the Yucatán Peninsula, Quintana Roo, Mexico. Zootaxa 3190: 31-46. https://doi. org/10.15468/ztlpt9

Nylander J.A.A. 2004. MrModeltest v2.3. Program distributed by the author.

Rambaut A., Suchard M.A., Xie D. \& Drummond A.J. 2014. Tracer v. 1.6. Available from http://beast. bio.ed.ac.uk/Tracer [accessed 27 Apr. 2017].

Reumont B.M. von \& Burmester T., 2010. Remipedia and the evolution of hexapods. eLS. https://doi. org/10.1002/9780470015902.a0022862

Rodríguez F., Oliver J.L., Marín A. \& Medina J.R. 1990. The general stochastic model of nucleotide substitution. Journal of Theoretical Biology 142: 485-501. https://doi.org/10.1016/S0022$\underline{5193(05) 80104-3}$

Ronquist F. \& Huelsenbeck J.P. 2003. MrBayes 3: Bayesian phylogenetic inference under mixed models. Bioinformatics 19: 1572-1574. https://doi.org/10.1093/bioinformatics/btg180 
Smart P.L., Beddows P.A., Coke J., Doerr S., Smith S. \& Whitaker F.F. 2006. Cave development on the Caribbean coast of the Yucatán Peninsula, Quintana Roo, Mexico. In: Harmon R.S. \& Wicks C. (eds) Perspectives on karst geomorphology, hydrology, and geochemistry - A tribute volume to Derek C. Ford and William B. White: 105-128. Geological Society of America Special Paper 404, Boulder (CO), USA. https://doi.org/10.1130/2006.2404(10)

Spaw R.H. 1978. Late Pleistocene carbonate bank deposition: Cozumel Island, Quintana Roo, Mexico. Gulf Coast Association of Geological Societies Transactions 28: 601-619.

Tamura K., Stecher G., Peterson D., Filipski A. \& Kumar S. 2013. MEGA6: molecular evolutionary genetics analysis version 6.0. Molecular Biology and Evolution 30: 2725-2729. https://doi.org/10.1093/ $\underline{\text { molbev/mst197 }}$

Thompson J.D., Higgins D.G. \& Gibson T.J. 1994. CLUSTAL W: improving the sensitivity of progressive multiple sequence alignment through sequence weighting, position-specific gap penalties and weight matrix choice. Nucleic Acids Research 22: 4673-4680.

Uchupi E. 1973. Eastern Yucatán continental margin and western Caribbean tectonics. Bulletin of the American Association of Petroleum Geologists 57: 1075-1095.

Ward W.C. 1997. Geology of coastal islands, northeastern Yucatan Peninsula. In: Vacher H.L. \& Quinn T. (eds) Geology and Hydrogeology of Carbonate Islands: 275-298. Developments in Sedimentology 54, Elsevier, Amsterdam.

Weidie A.E. 1989. Geology of the Yucatan Platform. In: Ward E.C., Weidie A.E. \& Back W. (eds) Geology and Hydrogeology of the Yucatan and Quaternary Geology of the northeastern Yucatan Peninsula: 1-19. New Orleans Geologic Society, New Orleans.

Yager J. 1981. Remipedia, a new class of Crustacea from a marine cave in the Bahamas. Journal of Crustacean Biology 1 (3): 328-333. https://doi.org/10.2307/1547965

Yager J. 1987. Speleonectes tulumensis n. sp. (Crustacea: Remipedia) from two anchialine cenotes of the Yucatan Peninsula, Mexico. Stygologia 3: 160-166.

Yager J. 2013. Speleonectes cokei, new species of Remipedia (Crustacea: Speleonectidae) from a submerged ocean cave near Caye Chapel, Belize. Zootaxa 3710: 354-362. https://doi.org/10.11646/ zootaxa.3710.4.4

Yager J. \& Carpenter J.H. 1999. Speleonectes epilimnius new species (Remipedia, Speleonectidae) from surface water of an anchialine cave on San Salvador Island, Bahamas. Crustaceana 72: 965-977. https://doi.org/10.1163/156854099503861

Yañez-Mendoza G., Zarza-González E. \& Mejía-Ortíz L.M. 2007. Sistemas anquihalinos. In: MejíaOrtíz L.M. (ed.) Biodiversidad acuática de la Isla de Cozumel: 49-70. Universidad de Quintana RooCONABIO, Plaza y Valdés, Mexico.

Manuscript received: 18 July 2016

Manuscript accepted: 11 October 2016

Published on: 5 May 2017

Topic editor: Rudy Jocqué

Desk editor: Kristiaan Hoedemakers 
Printed versions of all papers are also deposited in the libraries of the institutes that are members of the EJT consortium: Muséum national d'Histoire naturelle, Paris, France; Botanic Garden Meise, Belgium; Royal Museum for Central Africa, Tervuren, Belgium; Natural History Museum, London, United Kingdom; Royal Belgian Institute of Natural Sciences, Brussels, Belgium; Natural History Museum of Denmark, Copenhagen, Denmark; Naturalis Biodiversity Center, Leiden, the Netherlands; Museo Nacional de Ciencias Naturales-CSIC, Madrid, Spain; Real Jardín Botánico de Madrid CSIC, Spain. 